\title{
Is Carolene Products Dead? Reflections on Affirmative Action and the Dynamics of Civil Rights Legislation
}

\author{
Daniel A. Farber \\ Philip P. Frickey
}

TABLE OF CONTENTS

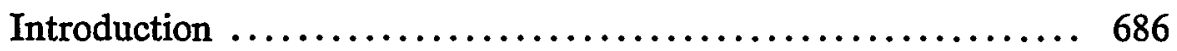

I. Carolene Products: The Implications of the Public Choice

Critique ...................................... 689

A. The Supreme Court's Limited Use of Carolene
Products' Political Theory ....................... 691

B. Clarifying the Implications of a Successful Carolene Products Critique............................ 697

II. An Analysis of the Public Choice Critique .............. 699

A. Ackerman's Critique of Carolene Products .......... 699

B. Critiquing the Critique: Flaws in the Public Choice

Model as Apphied to Racial Minorities ............. 701

1. Theoretical Shortfalls ...................... 702

2. Do Racial Minorities Have Political Parity? ...... 703

3. The Politics of Affirmative Action .............. 708

a. The 1964 Civil Rights Act................ 709

b. The Birth of Affirmative Action ............ 711

c. Affirmative Action From Ford to Bush........ 713

III. Carolene Products and the Future of Affirmative Action in the Supreme Court........................... 716

A. Affirmative Action and Carolene Products Today: An Uneasy Equilibriuin ....................... 717

B. Stare Decisis and the Future of Affirmative Action .... 720 Conclusion .................................... 727 


\title{
Is Carolene Products Dead? Reflections on Affirmative Action and the Dynamics of Civil Rights Legislation
}

\author{
Daniel A. Farber† \\ Philip P. Frickey $\ddagger$
}

\section{INTRODUCTION}

According to conventional wisdom, judicial protection of racial minorities is justified on the basis of their lack of political power. ${ }^{1}$ This rationale is grounded in the famous footnote four of Justice Stone's Carolene Products ${ }^{2}$ opinion, which suggested a "inore searching judicial scrutiny" to protect "discrete and insular minorities" when prejudice "tends seriously to curtail the operation of those political processes ordinarily to be relied upon to protect minorities."3 At least three basic problems arise from this understanding.

First, the conventional wisdom suggests that the civil rights revolution epitomized by Brown v. Board of Education ${ }^{4}$ rests on no firmer basis than positive political theory. As such, it divests Brown and related cases

$\dagger$ Henry J. Fletcher Professor of Law, University of Minnesota. B.A. 1971, M.A. 1972, University of Illinois; J.D. 1975, University of Illinois.

$\ddagger$ Professor of Law and Julius E. Davis Professor of Law for 1990-91, University of Minnesota. B.A. 1975, University of Kansas; J.D. 1978, University of Michigan.

We thank Bruce Ackerman, Roy Brooks, John Hart Ely, William N. Eskridge, Jr., Daniel B. Rodriguez, and Suzanna Sherry for comments on earlier drafts.

1. See, e.g., J. Ely, Democracy AND Distrust 77-88 (1980); L. LUSKY, By What Right? (1975); Ackerman, Beyond Carolene Products, 98 HARV. L. Rev. 713, 714-16 (1985); Balkin, The Footnote, 83 Nw. U.L. REv. 275, 283 (1989); Ball, Judicial Protection of Powerless Minorities, 59 IOWA L. REV. 1059, 1061-63 (1974); Brilnayer, Carolene, Conflicts and the Fate of the "InsiderOutsider," 134 U. PA. L. REv. 1291, 1292 (1986); Cover, The Origins of Judicial Activism in the Protection of Minorities, 91 YALE L.J. 1287, 1296-97 (1982); Lusky, Footnote Redux: A Carolene Products Reminiscence, 82 Colum. L. Rev. 1093, 1103-05 (1982); Powell, Carolene Products Revisited, 82 COLUM. L. REV. 1087, 1088-89 (1982).

2. United States v. Carolene Prods. Co., 304 U.S. 144, 152 n.4 (1938). While Carolene Products used the words "minorities," the Court's focus at that time, and for approximately the next 50 years, was primarily on one racial ninority-African Americans. This paper reflects that concentration. The experience of cach minority within the United States varies, and this paper does not attempt to discuss the past or current position of each.

3. Id. Footnote four is quoted at length at infra text acconpanying note 13 .

4. 347 U.S. 483 (1954). 
of much of their normative power while simultaneously rendering them vulnerable to attack as rooted in weak political science.

Second, the focus on political powerlessness may seem in tension with current reality. The potitical situation of racial minorities is far different from what it was in 1938, when Carolene Products was decided, or in 1954, when the Court decided Brown. In particular, a series of recent congressional "Civil Rights Restoration Acts" seems to attest to the political power of racial minorities, ${ }^{5}$ as does the apparent legislative support for affirmative action programs. Solne would argue that these developments suggest that the Carolene Products rationale may be an outmoded relic of an earlier era of race relations.

Third, by focusing on political powerlessness, the conventional rationale can lead to more "searching judicial inquiry" whenever positive political theory suggests that soine group is systematically disadvantaged in the political process. The theory has thus been subject to Justice Scalia's iromic mvocation of it, not as a shield protecting racial minorities against discrimination, but as a sword agamst affirmative action measures. ${ }^{6}$ If Justice Scalia is right, Carolene Products is defunct as a justification for protecting racial minorities, whom he characterizes as organized groups that pohticians are eager to please. Indeed, Justice Scalia's argument flips Carolene Products completely: it is the members of the majority who are politically powerless and in need of judicial protection. ${ }^{7}$

Justice Scalia's argument finds apparent support in an influential article by a highly unlikely ideological bedfellow, Bruce Ackerman. ${ }^{8}$ Drawing on the writings of public choice theorists, Ackerman argued that Carolene Products was wrong in suggestimg that discrete minorities need special protection from the political process; instead, it is diffuse,

5. See H.R. 4000, 101st Cong., 2d Sess. (1990); S. 2104, 101st Cong., 2d Sess. (1990); H.R. CONF. REP. No. 856, 101st Cong., 2d Sess. (1990). President Bush vetoed the legislation, and subsequent congressional attempts to override the veto failed. Other important civil rights restoration acts include the Civil Rights Restoration Act of 1987, Pub. L. No. 100-259, 102 Stat. 28 (1988) (codified at 20 U.S.C. $\$ 1687$ (1988)); Handicapped Children's Protection Act of 1986, Pub. L. No. 99-372, 100 Stat. 796 (codified at 20 U.S.C. $\$ 1415(\mathrm{e})(4)(B)-(G)(1988)$ ); Voting Rights Act Amendments of 1982, Pub. L. No. 97-205, 96 Stat. 131 (codified at 42 U.S.C. $\$ 1973(b)$ (1988)); Pregnancy Discrimination Act, Pub. L. No. 95-555, 92 Stat. 2076 (1978) (codified as amended at 42 U.S.C. $\S 2000 \mathrm{e}(\mathrm{k})(1988)$ ); Civil Rights Attorney's Fees Awards Act of 1976, Pub. L. No. 94-559, 90 Stat. 2641 (codified as amended at 42 U.S.C. $\S 1988$ (1988)). Some of these statutes are oriented less toward the concerns of racial minorities than toward other disadvantaged groups, such as women. Notably, some of these other groups are less "discrete and insular" than racial minorities but have had substantial legislative success.

6. See infra text accompanying notes 114-19.

7. Although Justice Scalia's argument was made in the sex discrimination context, we take it he meant to speak generally about affirmative action, and his argument is at its strongest in the setting discussed in the text.

8. See Ackerman, supra note 1 . 
large groups whose interests are likely to be underrepresented. ${ }^{9}$ Ackerman did not seem to have had affirmative action in mind, but his theory fits Justice Scalia's assertions well, and Ackerman's critique may have the umintended results of justifying a more relaxed judicial approach to discrimination against racial minorities and supporting Justice Scalia's stance toward affirmative action. ${ }^{10}$

Although Justice Scalia's views have rarely been articulated as clearly by others, we doubt he is alone in thinking that racial minorities form a powerful interest group and are more than capable of taking care of themselves through the political process, thus having no particular need for special judicial solicitude. ${ }^{11}$ This Article is a critical examination of the implications of this perspective on the politics of race. In particular, we suggest that the three problems we have identified arise out of a fundamental misunderstanding of the role that Carolene Products has played in public law and an incomplete appreciation of the politics of race.

In Part I, we begin by considering the positive political theory of Carolene Products and the Court's actual practice in protecting racial minorities since that decision. In our view, the Court's decisions protecting racial minorities from discrimination are rooted in considerations that go beyond political powerlessness. Hence, the possible imperfections of Carolene are less crucial than many might suppose. The implications of Carolene's demise would certainly not extend so far as to undermine bedrock civil rights cases such as Brown v. Board of Education.

Nonetheless, because the public choice critique of Carolene Products could lead to a modified judicial stance in discrimination cases, Part II addresses the Ackerman critique directly. Although his analysis is theoretically powerful, it does not match political reality. Despite the enormous gains of the last three decades, it would be a serious mistake to conclude that racial minorities have achieved full political equality. At a minimum, because the empirical underpinnings of Carolene Products have not been demonstrably eroded in the racial discrimination context, we caution agamst rejecting the Carolene Products approach in racial dis-

9. See infra text accompanying notes 60-71.

10. Ackerman did not mean to undermine the current law requiring rigid scrutiny in traditional racial discrimination cases, but meant to suggest that the focus of equal protection theory should be expanded to consider other disadvantaged groups, such as gay men and lesbians, who cannot fit the definition of a discrete and insular minority. See Ackerman, supra note 1, at 717-18. Our fear, however, is that any erosion of Carolene Products is likely to precipitate a retreat from rigid scrutiny, not an expansion of that scrutiny to new ground.

11. For a view similar to Justice Scalia's, see N. GLAZER, Ethnic Dilemmas 1964-1982, at 177-81 (1983). See also Easterbrook, Foreword: The Court and the Economic System, 98 HARv. L. REv. 4, 55-56 (1984) (characterizing title VII as special interest legislation that the Court has interpreted as a careful compromise). 
crimination cases as a matter of constitutional theory or interpretive practice.

We then turn specifically to the pohitical situation of those individuals who are disadvantaged by affirmative action. In contrast to Justice Scaha's position, we conclude that these individuals have not been impotent victims of a pohtical juggernaut. By and large, affirmative action has survived (at least at the federal level) as the result of normal pluralist politics, in which the opponents have not lacked for a voice. Minority success has been partly the result of luck, strong allies, and skillful lobbying, rather than simply overwhelming political clout.

Finally, Part III considers some of the legal implications of these political dynamics for future affirmative action disputes. First, we suggest that judicial hostility toward affirmative action cannot be defended on the basis of any empirical argument that the losers under affirmative action suffer from systematic political disadvantages. Second, we argue that the Court's decisions authorizing private affirmative action are now an accepted part of the legal fabric, on which there lias been significant societal reliance. Thus, a sensitivity to current social and political dynamics actually favors retaining these precedents.

Carolene Products: The Implications of the Public Choice Critique

Carolene Products was part of the Court's dramatic change of course in the late 1930s, in whicl it abandoned strict scrutiny of economic regulations and adopted a new role for itself in protecting civil rights and liberties. The opimion by Justice Stone upheld a federal statute ${ }^{12}$ prohibiting the interstate shipment of "filled milk," in which vegetable oil lias replaced the butter fat. Justice Stone deferred to a congressional finding that filled milk was imjurious to the public health because it was not as nourishing as "pure milk." Carolene Products reduced the degree of judicial scrutiny applicable to economic regulation, and it suggested, in its famous footnote four, a new set of roles for the Supreme Court. The footnote states:

There may be narrower scope for operation of the presumption of constitutionality when legislation appears on its face to be within a specific prohibition of the Constitution, such as those of the first ten amendments, which are deemed equally specific when held to be embraced within the Fourteenth.

It is unnecessary to consider now whether legislation which restricts those political processes which can ordinarily be expected to bring about

12. Filled Milk Act of 1923 , ch. 262,42 Stat. 1486 (codified as amended at 21 U.S.C. $\S \S 61-63$ (1988)). 
repeal of undesirable legislation, is to be subjected to more exacting judicial scrutiny under the general prohibitions of the Fourteenth Amendinent than are inost other types of legislation. On restrictions upon the right to vote, see Nixon v. Herndon, 273 U.S. 536; Nixon v. Condon, 286 U.S. 73.

Nor need we enquire whether similar considerations enter into the review of statutes directed at particular rehigious, Pierce v. Society of Sisters, 268 U.S. 510, or national, Meyer v. Nebraska, 262 U.S. 390, or racial minorities, Nixon v. Herndon, supra; Nixon v. Condon, supra: whether prejudice against discrete and insular minorities inay be a special condition, which tends seriously to curtail the operation of those political processes ordinarily to be rehed upon to protect minorities, and which may call for a correspondingly more searching judicial inquiry. ${ }^{13}$

Footnote four encompasses much of the ensuing half-century of constitutional law. The first paragraph foreshadowed the expansion of the guarantees of the first, fourth, fifth, sixth, and eighth amendments and their apphication to the states. ${ }^{14}$ The second paragraph is concerned with "clearing the channels of political change," to use John Hart Ely's phrase, ${ }^{15}$ as the citation to the "white primary" cases inakes clear. The third paragraph speaks primarily toward equal protection doctrine, which has grown from being the "last resort of constitutional arguments," as Holmes once called it, ${ }^{16}$ to a mainstay of constitutional law.

Our primary interest im this Article is in the third paragraph of footnote four. That paragraph suggests that the strategy of the second paragraph, standing alone, is insufficient to promote fair politics. For example, even if the formal rules governing the electoral process are fair, a "discrete and insular minority" that the majority disdains is still almost certam to lose. The key to the third paragraph seems to be "prejudice," a distortion of the pohtical process under which certain minorities are rendered pohtically powerless.

The Scaha/Ackerman critique challenges the empirical assumptions of the third paragraph. According to this view, Carolene Products is bad political science: Why should the judiciary protect "discrete and insular minorities" who have a pohtical edge over broad, diffuse inajorities? The practical imphications of this criticism should be addressed before we turn to its particulars. On the surface, the charge that the positive theory of Carolene Products is wrongheaded seems to call into question many Supreme Court decisions striking down official action disadvantaging

13. Carolene Products, 304 U.S. at 152 n.4 (additional citations omitted).

14. For a discussion of application of the Bill of Rights to the states, see L. TRIBE, AMERICAN Constrtutional LAw § 11-2 (2d ed. 1988).

15. J. ELY, supra note 1, at 105-34.

16. Buck v. Bell, 274 U.S. 200, 208 (1927). 
racial minorities. In this Part, we argue that, in fact, the implications of the critique are narrower.

\section{A. The Supreme Court's Limited Use of Carolene Products' Political Theory}

Carolene Products conceptualized the judicial role in cases not involving "specific prohibition[s] of the Constitutiou"17 as one of correcting flaws in the political process ratlier tlian defining substantive moral rights. In one of tlie inost important books on constitutional law of this generation, John Hart Ely used footnote four as the basis for a "process theory" of judicial review. Ely argued that courts can play an important role in enhancing the representativeness of the political process. For example, Reynolds v. Sims, ${ }^{18}$ the "one person, one vote" decision, enhanced the majoritarianisin of the political process along the lines suggested by paragraph two of footnote four. Unfair majoritarianism, the problem addressed in paragrapli three, is anieliorated by striking down legislation motivated by prejudice aganist discrete and insular minorities. ${ }^{19}$ Ely's book had the twin virtues of explaining most of the Warren Court's constitutional innovations, while linking those decisions togetlier in a grand but limited theory of judicial review.

Ely's work drew immediate criticism from important commentators who challenged his effort to ground judicial review in process theory. ${ }^{20}$ This flurry of commentary has obscured the fact that Carolene Products is not even cited, much less relied upon in any axiomatic way, in Brown or any of the other traditional racial discrimination cases. ${ }^{21}$

These opinions do not, as Carolene Products' footnote arguably did,

17. 304 U.S. at 152 n.4.

18. 377 U.S. 533 (1964)

19. See, e.g., Brown v. Board of Educ., 347 U.S. 483 (1954). Ely argues that the Constitution is concerned mostly with structure and process, and that lawyers and judges, although not experts on what the right political answer should be, are experts on what process to follow in order to reach an answer. Thus, "one person, one vote" is an appropriate constitutional rule because it concerns only the process of representation. In contrast, consider a ruling that a state law prohibiting termination of hife support violates a federal constitutional "right to die." In Ely's view, this holding is not good constitutional law, at least so long as such persons are fairly represented in the political process, because this rule is directed at the right political answer, not the right political process. These messages permeate chapters four through six of Ely's book; one concise statement along these lines appears in J. ELY, supra note 1, at 75 n.*.

20. See, e.g., Tribe, The Puzzling Persistence of Process-Based Constitutional Theories, 89 Yals L.J. 1063 (1980); Tushnet, Darkness on the Edge of Town: The Contributions of John Hart Ely to Constitutional Theory, 89 YALE L.J. 1037 (1980).

21. One looks in vain for any mention of Carolene in those cases-from Brown through Loving v. Virginia, 388 U.S. 1 (1967)-in which racial minorities asked the Court to strike down facial racial classifications. In addition, the Court did not cite to Carolene in any of the civil rights cases decided before Brown. Even the white primary cases following Carolene-Terry v. Adams, 345 U.S. 461 (1953), and Smith v. Allwright, 321 U.S. 649 (1944)-which could have relied upon either paragraph two or paragraph thrce of Carolene's footnote-failed to cite it. Nor did the Court cite 
begin with the assumption of a freewheehing pohtical process and then award automatic exemptions from pluralistic defeats to "discrete and insular" groups lacking political power. Instead, these opinions start more concretely with the social consequences of the allegedly discriminatory statute under attack. For example, Brown asks not whether the Kansas legislative process was polluted by "prejudice" against a "discrete and imsular minority," but rather whether a law segregating black children througl an explicit racial classification causes stigina-whether it "generates a feeling of inferiority as to their status in the coinmunity that may affect their hearts and minds in a way untikely ever to be undone." ${ }^{22}$ Loving $v$. Virginia ${ }^{23}$ stresses that facial racial classifications which harm minorities contradict "[t]he clear and central purpose of the Fourteenth Amendment," which "was to eliminate all official state sources of invidious racial discrimination in the States." 24 Clearly, these cases are rooted in concrete normative vision inore than axiomatic political theory.

Even more surprisingly, Carolene Products was not cited in cases where the Court was more overtly concerned with perfecting the pluralistic political process. Consider, for example, Washington v. Davis ${ }^{25}$ and its progeny, ${ }^{26}$ in which the Court considered whether facially neutral statutes that disproportionately disadvantage a racial minority violate the equal protection clause. To be sure, in concluding that such statutes embody unconstitutional racial discrimination only if they were adopted for discriminatory reasons, Davis and its progeny do correspond to footnote four's emphasis on "prejudice" agamst discrete and insular minorities as a pollutimg political influence. Yet "prejudice" is subject to a variety of defimitions. The requirement of intentional discrimination adopted in Davis and explained in later cases ${ }^{27}$ is far narrower than some other plausible formulations, such as selective racial indifference, ${ }^{28}$ that

Carolene in voting apportionment cases like Gomillion v. Lightfoot, 364 U.S. 339 (1960) (gerrymandering motivated by racial discrimination is unconstitutional).

22. 347 U.S. at 494.

23. 388 U.S. 1 (1967).

24. Id. at 10.

25. 426 U.S. 229 (1976).

26. See, e.g., Hunter v. Underwood, 471 U.S. 222 (1985) (statute disenfranchising persons convicted of certain crimes found unconstitutional because legislature had adopted it for discriminatory rcasons); City of Memphis v. Greene, 451 U.S. 100 (1981) (city's decision to close off a residential street in a white neighborhood not motivated by discriminatory intent).

27. In Personnel Administrator v. Feeney, 442 U.S. 256 (1979), the Court stated that “' 'Discrimimatory purpose' . . . implies more than intent as volition or intent as awareness of consequences. It implies that the decisionmaker ... selected or reaffirmed a particular course of action at least in part 'becanse of,' not merely 'in spite of,' its adverse effects upon an identifiable group." Id. at 279 (citation omitted).

28. See Brest, The Supreme Court, 1975 Term-Foreword: In Defense of the Antidiscrimination Principle, 90 HARV. L. REV. 1, 7-8 (1976) (suggesting that the equal protection clause should 
could also be used to address concerns about the systematic political disadvantages of "discrete and insular" minority groups.

The opinion in Davis seeins to turn far less on empirical assumptions about group power-for example, that the minority, as a group, is politically powerless to prevent the enactinent of certain harmful statutes or to achieve their repeal-than on a normative assumption that individuals should not be disadvantaged because of their race. ${ }^{29}$ Davis continually stressed that discrimination is unconstitutional only if it is "mvidious." In context, this term suggests that the true equal protection objection to inproperly motivated statutes that have a disparate impact upon a racial minority lies in the resentment, or stigma, or frustration individuals feel when victimized by prejudice in their own affairs-not merely in their meinbership in a minority group that lost a political struggle, even one lost for the wrong reasons. ${ }^{31}$

We do not inean to suggest that Ely was wrongheaded in pointing out that Carolene Products provides a theory to bolster Brown and its progeny, or that Carolene Products considerations are not a major part of the text $\mathrm{t}^{32}$ or subtext in many cases, or even that the Court "got it right"

prohibit state action rooted in "racially selective sympathy and indifference"- "the unconscious failure to extend to a minority the same recognition of humanity, and hence the same sympathy and care, given as a matter of course to one's own group"). For a more recent discussion, see Lawrence, The Id, the Ego, and Equal Protection: Reckoning With Unconscious Racism, 39 STAN. L. REV. 317 (1987) (suggesting that the equal protection clause should invalidate state action conveying a racist cultural meaning).

29. In Davis, plaintiffs' complaint was that a standardized test operated disproportionately to exclude blacks from a municipal police force. The Court stated:

As an initial matter, we have difficulty understanding how a law establishing a racially neutral qualification for employment is nevertheless racially discriminatory and denies "any person ... equal protection of the laws" simply because a grcater proportion of Negroes fail to qualify than members of other racial or ethnic groups. Had respondents, along with all others who failed Test 21 , whether white or black, brought an action claiming that the test denied each of them equal protection of the laws as compared with those who had passed with high enough scores to qualify them as police recruits, it is most unlikely that their challenge would have been sustained. . . . Respondents, as Negroes, could no more successfully claim that the test denied them equal protection than could white applicants who also failed. The conclusion would not be different in the face of proof that more Negroes than whites had been disqualified by Test 21 . That other Negroes also failed to score well would, alone, not demonstrate that respondents individually were being denied equal protection of the laws by the application of an otherwise valid qualifying test being administered to prospective police recruits.

426 U.S. at $245-46$.

30. See id. at $239-43$.

31. "Invidious" means "a) such as to excite ill will, odium, or envy; giving offense; b) giving offense by discriminating unfairly [invidious comparisons]." WEBSTER'S NEW WORLD DictionaRY (2d College ed. 1980) (brackets in original).

32. For example, in San Antonio Independent Scliool District v. Rodriguez, 411 U.S. 1 (1973), which held that scliool children residing in poor districts are not a suspect class, the Court failed to cite Carolene but, in a famous passage, considered heightened judicial solicitude to turn on whether "the class is . . . saddled with such disabilities, or subjected to such a history of purposeful unequal treatment, or relegated to such a position of political powerlessness as to command extraordinary protection from the majoritarian political process." Id. at 28 . As Justice Powell, who delivered the 
in each of these cases. We do mean to suggest, however, that the Court has been far more practical, and a good deal less theoretical, than Ely's analysis implies, and lias not built the foundation for these cases solely upon an axiomatic, positive theory of tlie political process. That theory was, after all, merely suggested

(1) backhandedly ("Nor need we enquire whetlier . . .")

(2) in dicta (not even in a case involving racial discrimination)

(3) in a footnote

(4) to whicll only four Justices subscribed. ${ }^{33}$

Nor lias the publication of Ely's book invigorated the Court's use of Carolene Products im inore recent cases involving alleged discrimination against racial minorities. Only one such opimion, Washington v. Seattle School District No. $1,{ }^{34}$ explicitly cites and relies upon the Carolene Products footnote. ${ }^{35}$ However, a close analysis reveals that the Seattle School District decision draws at least as inuch support from paragrapl two's concern about structural impediments to democracy as it does from paragraph three's concept of "discrete and imsular minorities."36

It is simply a myth, then, that the process theory of footnote four in Carolene Products is, or ever lias been, the primary justification for invalidatimg laws embodying prejudice against racial mimorities. What escapes view from the Carolene Products perspective is the normative side of the story. ${ }^{37}$ A successful critique of the positive theory of

opinion of the Court in Rodriguez, later stated, "the influence of Footnote 4 cannot be measured aceurately by simple enumeration of cases in which it has been cited." Powell, supra note 1, at 1087 n.4.

33. Footnote four is in the portion of Justice Stone's opinion in Carolene Products marked "Third." 304 U.S. at 152 n.4. Justice Black concurred in all of the opinion "except the part marked 'Third." "Id. at 155 . Justice Butler concurred only in the result, and Justice McReynolds simply noted his dissent. Id. Justices Cardozo and Reed did not participate in the case. Thus, only Chief Justice Hughes, Justice Brandeis, and Justice Roberts joined Justice Stone's footnote.

34. 458 U.S. 457 (1982).

35. In Seattle School District, a state statute adopted by initiative prohibited local school boards from assigning students away from their neighborhood schools, but contained exceptions covering virtually any educational purpose other than racial integration. Justice Blackmun's majority opinion striking down the law considered it an unfair reallocation of governmental decisionmaking power. $I d$. at 474 . The statute required racial minorities seeking integration through student assignment to obtain state legislation, while others seeking non-neighborhood school assignment could simply obtain approval from the school board. Id. Justice Blackmun stated that "when the State's allocation of power places unusual burdens on the ability of racial groups to enact legislation specifically designed to overcome the 'speeial condition' of prejudice, the governmental action seriously 'curtail[s] the operation of those political processes ordinarily to be relied upon to proteet minorities.' "Id. at 486 (quoting Carolene Products, 304 U.S. at 153 n.4).

36. The langnage from Seattle School District, quoted at supra note 35, is from paragraph three of footnote four, but the result in the case is also supported by paragraph two's concern about unfair structuring of the political process.

37. Scholars have sometimes recognized the normative issue. See, e.g., Ackerman, supra note 1, at 741-42 (arguing that while the "discrete and insular" rationale may be belied by reality, Carolene Products also stands for the necessary exclusion of "prejudice" from the workings of 
Carolene Products will thus not substantially undermine the theoretical underpinnings of the Brown constitutional revolution. Nor is there even the reinotest possibility that any Supreine Court in the foreseeable future would seek to overrule these well-established cases on this or any other basis. $^{38}$

Perhaps an even deeper myth is that Carolene Products itself granted racial minorities special judicial solicitude simply because (or only if) they are politically powerless discrete and insular minorities. By the time the Court decided Carolene Products, it had already struck down soine state efforts to deprive minorities of civil rights. ${ }^{39}$ Footnote four reflects that development, citing cases in which the Court had already shown itself willing to defend blacks, ${ }^{40}$ rehgious minorities, ${ }^{41}$ and minorities of different national origin ${ }^{42}$ against prejudicial laws. The reference to "prejudice against discrete and insular minorities" follows the citations of these cases, set off by an elusive colon.

Arguably, the portion of paragraph three preceding the colon recognizes that heightened judicial solicitude for these groups is the unquestioned baseline; the reference to "discrete and insular minority" following the colon niay refer to groups other than blacks and religious and national-origin minorities. Under this line of analysis, pohitical powerlessness is not a necessary precondition for heightened protection

pluralist democracy). In general, however, the scholarly community has failed to note that the Court itself has at times recognized this insight.

38. Consider the view of Richard Posner:

In addition to (but related to) the natural law justification offered earlier (Brown as vindication of a moral norm that was influential then and that now commands a consensus), consider what we would think of a decision by the Supreme Court overruling Brown tomorrow on the ground that the decision was an incorrect interpretation of the Fourteenth Amendment. We would pronounce such a decision wrong even if we agreed that it rested on a defensible theory of constitutional interpretation. The decision would be an enormous provocation, stirring racial fears and hostilities in a nation more rather than less racially heterogeneous than when Brown was decided; it would be promptly overruled by Congress in the exercise of its powers under section 5 [of the Fourteenth Amendment] or the commerce clause; it would unsettle all of constitutional law, most of which rests on interpretive grounds no more powerful (and often much less so) than those of Brown; and whatever its actual motivations it would be thought to bespeak the politicization of the Court. It would in short be socially, politically, and legally destabilizing.

R. Posner, The Problems of Jurisprudence 308 (1990).

39. In addition to the cases cited in Carolene, see Buchanan v. Warley, 245 U.S. 60 (1917) (ordinance establishing residential segregation); Guinn v. United States, 238 U.S. 347 (1915) (grandfather clause excluding blacks from franchise); Strauder v. West Virginia, 100 U.S. 303 (1879) (discrinination in jury selection).

40. E.g., Nixon v. Condon, 286 U.S. 73 (1932) (party cannot exclude blacks from voting in its primary); Nixon v. Hemdon, 273 U.S. 536 (1926) (same).

41. E.g., Pierce v. Society of Sisters, 268 U.S. 510 (1925) (states cannot require children to attend public, rather than parochial, schools).

42. E.g., Meyer v. Nebraska, 262 U.S. 390 (1923) (states cannot forbid the teaching of a foreign language). 
of the baseline groups, although lack of political power may justify heightened judicial solicitude for other groups in the future.

Leaving aside Justice Stone's intentions, which were probably contrary to this suggestion, ${ }^{43}$ it is worth noting that the Court's practice since Carolene Products has been consistent with this reading. Carolene Products has been prominently cited, not in cases involving prejudiced acts against blacks or religious or national-origin minorities, but in opinions considering whether other groups deserve more than rational basis review for protection against harmful legislation. The alienage cases reveal this most clearly, ${ }^{44}$ but it is also apparent in a case decided just two weeks before Brown, Hernandez v. Texas, ${ }^{45}$ in which the Court extended heightened scrutiny to protect Mexican Americans. More recently, Carolene Products has functioned alınost exclusively as a limiting principle under which state governments ${ }^{46}$ and the mentally retarded, ${ }^{47}$ for example, have failed to qualify for heightened protection.

Additionally, in the context of affirinative action, the Court has not found the presence or absence of a discrete and insular minority a significant factor in deternining the degree of judicial scrutiny. Justice Powell's opinion in Regents of the University of California v. Bakke 48 explicitly rejected the notion that strict scrutiny was applicable only when racial classifications disadvantage a discrete and insular minority. ${ }^{49}$ Justice O'Connor echoed his view, more recently, in Richmond v. J.A.

43. See generally Lusky, supra note 1 (giving the perspective of Justice Stone's law clerk, widely considered the scrivener of the footnote, on the evolution of the note and the context surrounding it). On the broader implications of the overall structure of the Carolene Products opinion, see Balkin, supra note 1, at 282-93 (analyzing footnote four from a law-and-literaturc perspective).

44. See, e.g., Graham v. Richardson, 403 U.S. 365, 372 (1971) (aliens "are a prime example of a 'discrete and insular' minority" (citing Carolene Products, 304 U.S. at 152 n.4). Classifications based on alienage are, of course, drawn on the basis of citizenship, not national origin.

45. 347 U.S. 475 (1954). In that case, a Mexican American challenged his indictment by a grand jury and conviction by a petit jury where Mexican Americans had been systematically excluded from both jury pools. The Court assumed that the equal protection clause provided heightened scrutiny for systematic exclusions of African Americans and then concluded that Mexican Americans constituted an analogous "distinct class" protected by the Constitution when "single[d] out ... for different treatment not based on some rcasonable classification." Id. at 478. Although the Court did not cite Carolene, there are obvious parallels between this approach and footnote four. An important difference, however, is that the Court in Hernandez did not mention political powerlessness per se as a criterion for higher scrutiny.

46. See South Carolina v. Baker, 485 U.S. 505, 513 (1988) (state government did not meet Carolene Products criteria of being politically isolated and powerless in the national political process).

47. See City of Cleburne v. Cleburne Living Cent., 473 U.S. 432, $443-46$ (1985) (although the majority opinion did not cite Carolene Products, it held that the mentally retarded do not warrant the protection of heightened scrutiny as they are not politically powerless).

48. 438 U.S. 265 (1978).

49. Id. at 290 . 
Croson Co. ${ }^{50}$ Most recently, in Metro Broadcasting v. FCC, ${ }^{51}$ Justice Brennan's majority opinion upholding a federal affirmative action measure neither cited Carolene Products nor invoked the idea-rejected by Justice Powell in Bakke-that heightened judicial solicitude was called for only when a racial classification disadvantaged a discrete and insular minority. ${ }^{52}$ Thus, even if Carolene Products embodied a perfect political inodel, a majority of the Court has not found that theory either necessary in some circumstances or sufficient in others to lower the degree of judicial scrutimy of "bemign" racial classifications.

\section{B. Clarifying the Implications of a Successful Critique of Carolene Products}

Revealing the Court's minimal reliance on the political theory of Carolene Products is not to say that Carolene Products is unimportant. It is to suggest, however, that it is time to separate the symbolic meaning of Carolene Products from the political theory it espoused. On the former, Robert Cover said it well:

Each constitutional generation organizes itself about paradigmatic events and texts. For my generation, it is clear that these events are Brown v. Board of Education and the civil rights movement and that the text is footnote four. For, whether or not the footnote is a wholly coherent theory, it captures the constitutional experience of the period from 1954 to 1964 . And that experience, more than the logic of any theory, is the validating force in law..$^{53}$

As Cover suggested, Carolene Products may have worked well as a mood piece, signaling a change of direction in judicial solicitude and scholarly focus. ${ }^{54}$ If Carolene Products works less well today as "coherent theory," to use Cover's term, that is surely of less importance. Strictly read, Carolene Products relied largely on a positive political theory subject to

50. 488 U.S. 469, 493-98 (1989) (plurality opinion). Justice O'Connor, however, noted that under Carolene some have argued that affirmative action is not a serious equal protection problem "when the "white majority' places burdens upon itself." Id. at 495 (citing J. ElY, supra note 1, at 170). Ultimately, she turned that argument against the ordinance in question because it had been adopted in a city with a black majority by a city council with a black majority. Id. We will later argue that racial representation in legislatures is a significant factor in applying Carolene Products. See infra text accompanying notes 101-13. We believe, however, that Carolene should not be applied on a locality-by-locality basis. Moreover, Justice O'Connor failed to inquire whether whites were underrepresented on the Richmond city council (and if so, whether the reasons involved prejudice).

51. 110 S. Ct. 2997 (1990) (upholding program awarding enhancement for minority ownership in proceedings for new liccnses and encouraging transfer of some stations to minority-controlled firms).

52. In a nutshell, Justice Brennan concluded that Congress had unique powers to engage in affirmative action. See id. at 3008-09.

53. Cover, supra note 1 , at 1316.

54. In addition, see Fiss, The Supreme Court, 1978 Term-Foreword: The Forms of Justice, 93 HARV. L. REV. 1, 6 (1979) (commenting that footnote four of Carolene is "[t]he great and modern charter for ordering the relation between judges and other agencies of government"). 
challenge at every turn. The Court's actual practice has fit less with this strict reading of Carolene Products than with its broader spirit of solicitude for "out-groups." That spirit is imphicit in the reference to "prejudice," since the difference between a prejudice and a justified preference is normative. 55

Of course, even if Brown and its progeny are secure, other important imphications may flow from the conclusion that Carolene Products flunks modern political science. We will consider two obvious possibilities. Both could result if, contrary to Carolene Products, the courts come to view discreteness and msularity of racial minorities as political advantages.

The first is an unquantifiable attitudinal shift within the judiciary that could diminish judicial solicitude for the civil rights of racial minorities. Legislative victories for these groups would lose the patina of hardfought moral struggles, becoming instead predictable normal politics. Judges would be less likely to view civil rights statutes as embodying "public values" to be promoted broadly through judicial interpretation, ${ }^{56}$ and more likely to consider them just like any other statutes, to be interpreted without any special considerations. As we will suggest later, it is premature to conclude that racial mimorities have achieved parity in our society, or that civil rights controversies have become routine legal disputes. ${ }^{57}$

A second and more dramatic effect may occur if this trend continues a few steps further. Instead of a mere lack of judicial enthusiasm for civil rights legislation, we may encounter active judicial skepticism of the legitimacy of affirmative action measures. Indeed, Justice Scalia has already suggested ${ }^{58}$ that statutes embodying explicit racial classifications for affirmative action purposes should not be seen as virtuous attempts to recognize the rightful claims of oppressed minorities-for example, to remedy the present effects of past discrimination or to promote a more harmomious racial future. Rather, they look constitutionally suspect, for the beneficiaries (discrete and insular mimorities) seem to have substantially more political power than the losers (diffuse, unorganized members of the majority-whites, males, and so on). ${ }^{59}$

55. See infra note 107 and accompanying text.

56. On the notion that such public values are incorporated in interpretation, see Eskridge, Public Values in Statutory Interpretation, 137 U. PA. L. REv. 1007, 1032-34, 1047-48 (1989) (statutory interpretation in cases involving "Carolene groups"); Sunstein, Interpreting Statutes in the Regulatory State, 103 HARV. L. REv. 405, 483-85 (1989) (statutory interpretation in the context of employment discrimination).

57. See infra text accompanying notes 85-113.

58. See supra text accompanying notes 6-7.

59. Whether males should be classified as a majority group is unclear. Although males are slightly less numerous than females, and thus technically a minority group, their overwhelining 
In snm, although the abandonment of Carolene Products would not undermine the Brown revolution where either explicit racial classifications or prejudiced actions harm minorities, it could seriously undercut the appeal of antidiscrimination laws and affirmative action measures. Accordingly, we turn to the Scalia/Ackerman critique to determine whether it provides a foundation for sucl judicial skepticism.

\section{II}

\section{An Analysis of the Public Choice Critique}

\section{A. Ackerman's Critique of Carolene Products}

Bruce Ackerman has forcefully argued that Carolene Products is bankrupt as a matter of political theory:

Carolene is utterly wrongheaded in its diagnosis. Other things being equal, "discreteness and insularity" will normally be a source of enorinous bargaining advantage, not disadvantage, for a group engaged in plurahist American politics. Except for special cases, the concerns that underlie Carolene should lead judges to protect groups that possess the opposite characteristics from the ones Carolene emphasizes-groups that are "anonymous and diffuse" rather than "discrete and insular." It is these groups that both political science and American history indicate are systemnatically disadvantaged in a pluralist dennocracy. ${ }^{60}$

In an intellectual tour de force, Ackerman shows how each of the attributes specified in Carolene Products can be an advantage. For example, insularity produces several benefits. It breeds group solidarity, which leads imdividuals to make symbolic contributions as an expression of their group identity. ${ }^{61}$ It subjects potential "free riders" to social pressures, which are greater in an insular commumity than in a diffuse group. ${ }^{62}$ Finally, geographic concentration allows an insular group to exercise a decisive influence in a significant number of legislative districts; a group spread out more evenly may be too sinall in any given district to exercise mucl influence. ${ }^{63}$ Thus, Ackerman concludes, insularity is a source of power, and he points to the power of the farm bloc as a case in poimt. ${ }^{64}$

Sinilarly, Ackerman says, discreteness may be an advantage as well. It nnakes group nnembers easily identifiable. If they cannot readily exit from the group, they have a strong imcentive to assist in its efforts. ${ }^{65}$ Of

majority in positions of political power arguably justifies considering them a majority under the Carolene Products analysis.

60. Ackerman, supra note 1 , at 723-24.

61. Id. at 725 .

62. Id.

63. Id. at 727 .

64. Id. at 728 .

65. Id. at 730-31. 
particular relevance here is Ackerman's point that blacks cannot avoid the impact of racism and therefore have a strong incentive to participate in organized political action. ${ }^{66}$ Thus, groups defined by immutable traits have a political advantage.

Ackerman has thus explained the advantages minorities enjoy in hight of every inajor Carolene Products factor except one-prejudice. ${ }^{67}$ Here, Ackerman is simply skeptical that, whatever their private feelings, pluralist pohticians will give up the opportumity to enter into coalitions with powerful groups merely because of their own personal prejudices. ${ }^{68}$

Ackerman does not dispute the unconstitutionahty of excluding racial minorities from American political life, but he clearly regards this as virtually a thing of the past:

Although America has by no means worked itself clear of past practices of political exclusion, it is not visionary to hope that we will indeed put this grim aspect of history behind us and that, ... despite the existence of pervasive social prejudice, minorities can and do participate in large numbers within the normal political process. ${ }^{69}$

In support of this statement, he cites statistics about the rise in minority representation in Congress, from two blacks and one Hispanic in 1960 to twenty-one blacks and eleven Hispanics in the mid-eighties. ${ }^{70}$ In short, while Carolene Products was right for its time, it is rapidly being left by the wayside of history. ${ }^{71}$

Ackerman's critique of Carolene Products is firmly supported by public choice theory, particularly by Mancur Olson's theory of collective action. ${ }^{72}$ Olson explained that political action benefiting large groups is riddled with "free rider" problems. For example, everyone presumably benefits from improved national security, but an individual's actions in support of national security ordinarily promote it only infinitesimally. Thus, a rational individual will try to "free ride" on the efforts of others to promote national defense.

The "free rider" problem suggests that large groups of individuals

66. Id. at 730 .

67. Prejudice may have been the key to Justice Stone's own understanding of the footnote. See Bixby, The Roosevelt Court, Democratic Ideology, and Minority Rights: Another Look at United States v. Classic, 90 YALE L.J. 741, $762-67$ (1981).

68. See Ackerman, supra note 1, at 732-37 (criticizing "pariah model" of how politicians treat minority representatives).

69. Id. at 717 .

70. Id. at 733 n.35. Footnote 35 also notes that Hispanics comprised $6.4 \%$ of the total population in 1980, while footnote 14 notes that blacks were just under $12 \%$ of the population in 1980. Id. at 721 n. 14 .

71. See, e.g., id. at 742 (arguing that if Carolene is to be more than a "tircd formula," it must also address the systematic disadvantages of diffuse groups).

72. See M. Olson, The logic of Collective Action (1965); see also D. Farber \& P. Frickey, LAW AND PUblic Choice: A CRITICAL INTroduction 23-24 (1991) (discussion of the Olson thesis). 
seeking broadly dispersed public goods should find it difficult to organize. Instead, politics will be dominated by small groups of mdividuals seeking to benefit themselves. The easiest groups to organize should involve a few individuals or firms seeking government benefits for themselves, which will be financed by the slumbering general public. In a nutshell, if Olson is correct, politics should be dominated by "rent-seeking" special interest groups.

Olson's conclusions provide Ackerman with just the right ammunition to attack Carolene Products. ${ }^{73}$ Moreover, studies by economists as well as political scientists confirm that special interest groups do appear to play a major role in the legislative process. ${ }^{74}$ Thus, the Olson model appears to have a certain antount of theoretical and empirical force.

\section{B. Critiquing the Critique: Flaws in the Public Choice Model as Applied to Racial Minorities}

Despite the logic of the Ackerman model, a close exammation reveals that it does not accord with the current status of inmority groups in this country. The reinainder of this Part canvasses the shortfalls of this model on several levels. In general, we agree with Ackerman that discreteness and insularity are not in themselves political liabilities, except where they are linked with prejudices or other political disabilities. Ackerinan underestimates, however, the continuing impact of racial prejudice on the political process.

Section 1 examines the Ackernan model from a theoretical standpoint, critically analyzing some of its key assumptions. The Ackerman model fails to consider one of the most important factors in the dynamics of the pluralist political process: the role of ideology in systematically discriminating agamst minority groups. Additionally, we question Ackerman's assumption that minorities have perfect access to the political process. We conclude that these questions are important but only empirical analysis can provide the answers.

Thus, in Sections 2 and 3, we consider the problem from an empirical perspective. Section 2 addresses whether minority groups have achieved political parity. By comparing racial minority groups to other discrete and imsular groups, we find that the answer is not nearly as clearcut as Ackerman suggests. Then, in Section 3, we examine the political

73. See Ackerman, supra note 1, at 724-26 (explaining how insular groups are able to overcome the "free rider" problem).

74. See generally D. FARBER \& P. FRICKEY, supra note 72, at 12-37 (discussing the literature on interest groups). As Olson's model would predict, these groups generally represent relatively concentrated economic interests. In contrast, consumers - the most widely dispersed economic interest-remain underrepresented. See K. SChLozMAN \& J. TIERNEY, ORGANIZED INTEREsTS AND AMERICAN DEMOCRACY 74-87, 111, 128, 387-89 (1986) (statistics show that consumer groups accounted for only $10 \%$ of all citizens' groups in 1980). 
underpinnings of civil rights legislation passed in the last twenty years. This analysis suggests that Ackerman's model does not accurately explain the political dynamics of such legislation.

\section{Theoretical Shortfalls}

The primary flaw in the Ackerman model is that it neglects the importance of ideology. Ideology results in three deviations froin the behavior postulated by the model. First, the personal ideology of individual legislators appears to play some role in their voting. There is substantial empirical evidence that constituent interests and pressure from special interest groups calmot coinpletely explain legislative voting patterns. Rather, there remains a stubborn residual effect of the legislator's own ideology. ${ }^{75}$

Second, because ideology tends to give coherence to the legislator's position, voters can obtain a good deal of information about the legislator simply by knowing her general position ("she's a moderate conservative"). By making information about the legislator easier to obtain, ideological consistency also makes it more feasible for voters to make informed choices. Public choice posits that voters remain "rationally ignorant," but ideology provides voters witl a simple cue about a candidate's views.

Third, ideology mitigates the "free rider" problem by motivating citizens to engage in political activity (mcluding voting) that may not make much economic sense. ${ }^{76}$ Voting makes hittle economic sense because it takes time, and an individual vote is almost certain not to change the result. Ideology provides a motive for voting, and thus pohitical activity nay be a way of expressing personal ideological commitments. ${ }^{77}$

What Carolene Products calls prejudice may play the role of such a motivating ideology. The power a iminority group can inuster will be limited to the extent that other voters (and legislators) are ideologically motivated to suppress it. Moreover, part of the "pohtical processes ordinarily to be relied upon to protect minorities"78 may be a legislator's ideological coinmitment to fair treatment, which may not extend to "second-class citizens." Conversely, those who do not benefit from affirmative action-Justice Scaha's unorganized "majorities"-may have more power than public choice theory would suggest, because their interests may coincide with important ideological forces. Whether these

75. See D. FARBER \& P. FrickeY, supra note 72, at 29-33 (discussing economic and political science studies along these lines).

76. For further discussion, see $i d$. at 25-27 (criticizing attempts to reconcile popular voting behavior and public choice as tautological).

77. This assumption seems to underlie some of Ackerman's thoughts. See Ackerman, supra note 1 , at 720 (describing pluralistic politics).

78. See Carolene Products, 304 U.S. at 152 n.4. 
effects actually exist, and how powerful they are if they do, are empirical questions.

The public choice model also assumes that individuals have equal access to the political process. This may not be a valid assumption. As an extreme example, a small, well-organized group that is completely disenfranchised cannot be expected to exercise much legislative power. Ackerman explicitly assumes political equality exists, ${ }^{79}$ which he defines to include the existence of "election districts strictly conformed to the Court's reapportioument decisions," 80 the right to organize and speak freely on political topics, and parity in ballot access. ${ }^{81}$ To define the latter, Ackerman sometimes speaks of equal voter turnout, ${ }^{82}$ sometimes of participation in "large numbers," 83 and sometimes of the absence of "brutal efforts" to exclude blacks from the voting bootl1. ${ }^{84}$ Although the clioice among these standards was not important for Ackerman's purposes, it may affect the determination of whether blacks lave attained equal political access.

\section{Do Racial Minorities Have Political Parity?}

There can be no doubt that in the last twenty-five years, there has been "a radical shift in the rules of the political game."85 In just two years, from 1965 to 1967 , the percentage of blacks registered to vote in Mississippi rose tenfold. ${ }^{86}$ From 1965 to 1980 , the number of elected blacks im the South rose from less than 100 to over $1800 .{ }^{87}$ Nationwide, by 1988 , there were more than 7000 elected black officials, including the mayors of Chicago, Atlanta, Los Angeles, and other major cities. ${ }^{88}$ Moreover, black political power has been important in the passage of significant new civil rights legislation, ${ }^{89}$ as well as in other settings sucl as the defeat of the Bork nomination, ${ }^{90}$ not to mention the election of Jimmy Carter. ${ }^{91}$

79. See Ackerman, supra note 1, at 717 (limiting critique of Carolene Products to paradigm case of political equality).

80. Id. at 716.

81. Id. at 717 .

82. Id. at 716 (assuming political equality includes equal voter turnouts of all races).

83. Id. at 717 .

84. Id.

85. A. Thernstrom, Whose Votes Count? Affirmative Action and Minority Voting RighTS 2 (1987).

86. See id.

87. See id. at 3.

88. See S. Schmidr, M. Shelley \& B. Bardes, American Government and Politics TODAY 151 (3d ed. 1989).

89. See supra note 5 and accompanying text.

90. See Guinier, Keeping the Faith: Black Voters in the Post-Reagan Era, 24 HARv. C.R.-C.L. L. REv. 393, 414 (1989).

91. See R. Weisbrot, Freedom Bound: A History of America's Civil Rights 
Nevertheless, it is untenable to conclude that this undeniable progress has resulted in parity. Although there is no way to gauge political influence, it is far from clear that blacks have as inuch pohtical clout as other groups of similar size. For example, in 1980, the elderly made up about the same proportion of the population as blacks. ${ }^{92}$ Although no one has studied the issue, it seems clear to us that the elderly have had considerably more success in the legislative arena than have blacks. The virtually sacrosanct status of Social Security strongly attests to the soundness of this conclusion, as does an ever-expanding federal prohibition on age discrimination. ${ }^{93}$ Similarly, farmers now inake up only three percent of the population, considerably less than blacks, but their "influence on legislation beneficial to their interests has been enormous."94

In Carolene Products terms, both groups are probably at least as geographically diffuse as blacks, and at best no inore "discrete" in terms of ready identifiability. The elderly also profit greatly from the absence of another factor relating to prejudice: immutability. Younger voters know they will someday be elderly, and the proportion of legislators who remain in office long enough to becoine elderly is significant ${ }^{95}$ (although it has declined). ${ }^{96}$ Because the three groups (blacks, farmers, and the elderly) differ from each other in so many other ways, ${ }^{97}$ it is impossible to come to any firm conclusions about the role of Carolene Products factors in their relative political power. Even measuring the relative power of these groups is itself a dubious enterprise. A consideration of the great pohtical clout of these other groups does at least show that blacks are not particularly powerful compared to other groups of roughly similar size. Our impression, though certainly not subject to objective proof, is that blacks have in fact been less powerful than comparably sized groups. Blacks have either failed to profit from being a discrete and insular

MOVEMENT 299 (1990). For other dramatic examples of the increasing power of Southern black voters, see id. at 313-16. Even some of the most dyed-in-the-wool racists managed to change their stripes in response to the new political presence of black voters. Perhaps the most surprising examples involve the belated discovery of the norm of racial equality by Southern politicians George Wallace and James Eastland. Id. at 316.

92. The elderly were just over $11 \%$ of the population in 1980. C. MURRAY, Losing Ground: American Social POLicY, 1950-1980, at 60 (1984). Blacks make up $12 \%$ of the population. S. SChMIDT, M. SHelley \& B. BARDES, supra note 88, at 152.

93. See S. SChMiDT, M. Shelley \& B. Bardes, supra note 88, at 547 (Social Security a "political 'sacred cow'"); id. at 183 (on age discrimination statutes). The result of the Social Security system has been a massive transfer of income to the elderly. See M. HARRINGTON, THE New American Poverty 224-25 (1984).

94. S. SCHMIDT, M. SHELLEY \& B. BARDES, supra note 88, at 233.

95. In 1987, the Congress had 111 members over the age of 60. Id. at 184.

96. In 1971, the figure had been 148. Id.

97. Some of these differences themselves may be tied to Carolene factors. The elderly are more affluent than blacks, for example, but this may be in part due to their political success in securing huge wealth transfers through the Social Security system. 
minority, or any advantages that they have obtained are more than counterbalanced by the effects of prejudice.

Although political influence is virtually impossible to measure, political representation is not. Again, despite enormous progress, blacks are underrepresented in Congress. There were twenty-one blacks in the House by the mid-eiglities ${ }^{98}$ - a major gain, but far fewer than the fifty or so representatives that would be expected on a statistical basis. ${ }^{99}$ At the state level, despite impressive gains, the disparity is if anything more striking. ${ }^{100}$ We need to address three questions: Is this underrepresentation important? What are its causes? Are those causes relevant under Carolene Products?

As to the importance of the underrepresentation, there is no question that a white legislator can represent the interests of black constituents and that a black legislator can fail to do so. Nevertheless, we think as a matter of common sense that on average, black legislators are more likely to be better representatives of the interests of black constituents, particularly in situations where the legislator's personal ideology influences his or her voting. We do not base this view on any particular belief about racial consciousness. ${ }^{101}$ Instead, we consider it merely an example of the general phenomenon that legislators' personal views and backgrounds affect their behavior. ${ }^{102}$

98. See supra note 70 and accompanying text.

99. Achieving representation proportional to the population percentage may be an unrealistic expectation, of course, because of a host of factors including geographical concentration and voting district lines.

100. As to the gains, in the 7 states covered by the 1965 Voting Rights Act, blacks had won over 1800 elected positions by 1980 , including over 80 mayors. On the negative side, however, there were more than 32,000 elected officials in the covered states, giving blacks a mere 5\% share of the total seats. Black population shares ranged from approximately $19 \%$ to $35 \%$ in the 7 states. See S. Lawson, In Pursuit of Power: Southern Blacks and Electoral Politics, 1965-1982, at 264 (1985). (Note to employment discrimination scholars: Since there are no known qualifications for elected office, the population figures are the appropriate basis for comparison, rather than the qualified labor pool!)

101. We certainly have no desire to get caught in the cross-fire between Randall Kennedy and his critics about the existence of a unique black intellectual perspective. See Kennedy, Racial Critiques of Legal Academia, 102 HARV. L. REV. 1745 (1989); Ball, The Legal Academy and Minority Scholars, 103 HARV. L. REV. 1855 (1990) (responding to Kennedy's article); Barnes, Race Consciousness: The Thematic Content of Racial Distinctiveness in Critical Race Scholarship, 103 HARV. L. REv. 1864 (1990) (same); Brewer, Introduction: Choosing Sides in the Racial Critiques Debate, 103 HaRv. L. REv. 1844 (1990) (same); Delgado, Mindset and Metaphor, 103 HaRv. L. REV. 1872 (1990) (same); Espinoza, Masks and Other Disguises: Exposing Legal Academia, 103 HARV. L. REv. 1878 (1990) (same). We note, however, that a distinct black culture (consisting of elements both common to and different from those of the larger mainstream or white culture) may exist, and that such a black culture could inform a black political perspective. For further discussion of black culture, see R. Brooks, RETHinking the AMERICAN RACE Problem 137-49 (1990).

102. In Metro Broadcasting v. FCC, 110 S. Ct. 2997 (1990), a majority of the Court accepted the proposition that minority-owned stations were more likely to present minority perspectives in their broadcasting. Id. at 3016-19. For similar reasons, we think the same of ininority legislators. Unlike the Court, however, we need not concern ourselves with whether the correlation is strong 
There is empirical support for the proposition that a legislator's race matters. For example, public employment for blacks correlates with the proportion of blacks on the city council, all other things being equal. ${ }^{103}$ Also, a legislator's race influences voting on abortion issues regardless of the racial or ethmic composition of his or her constituency. ${ }^{104}$ More generally, the empirical evidence about legislator ideology shows that a legislator's personal views significantly affect voting. ${ }^{105}$ If legislators' personal views do matter, it seems clear that black legislators are likely to have different life experiences, and therefore different views than whites, on matters relating to race. Again, we wish to stress that we are not arguing that black legislators umquely represent the interests of blacks; only that all other things being equal, they are more likely to do so. ${ }^{106}$

The numerical underrepresentation of blacks, besides being inportant in its own right, may be an important symptom of a deeper problein. If the causes of black underrepresentation indicate that black voters are being "shut out" of the pohitical process to some degree, then the same factors will also decrease their abihty to influence white legislators. For exainple, if white voters shun black candidates, legislators inay find it advantageous to distance themselves from identifiably pro-black positions. Racial bloc voting by whites, then, should be a factor of grave concern that cautions against any impulse to abandon Carolene Products. For, leaving aside the technicalities of interpreting what constitutes "prejudice against a discrete and insular ininority," this sort of majority bloc voting establishes the gist of the Carolene Products point: the political problems of "out-groups." 107

Although there has been substantial progress, a brief overview of recent developments in voting rights demonstrates that white racial bloc voting continues to undermine black voting strength. In Mobile v. Bolden, ${ }^{108}$ the Supreme Court upheld a numicipal at-large electoral schenie that allowed a white bloc-voting inajority to elect the candidates of its choice. In response to the judicially imposed requirentent of proof

enough to survive heightened scrutiny, since we are not proposing a minority set-aside within the legislature.

103. See Mladenka, Blacks and Hispanics in Urban Politics, 83 AM. PoL. Sc1. Rev, 165, 172-75 (1989).

104. See Page, Shapiro, Gronke \& Rosenberg, Constituency, Party, and Representation in Congress, 48 PuB. Opinion 741, 752 (1984).

105. See supra note 75 and accompanying text.

106. For a general discussion of the importance of minority representation in legislatures, see Abrams, Raising Politics Up: Minority Political Participation and Section 2 of the Voting Rights Act, 63 N.Y.U. L. REV. 449 (1988).

107. Writing only four years after Carolene Products, Louis Lusky, the law clerk who drafted footnote four, explained that it was designed to protect "out-groups." See Lusky, Minority Rights and the Public Interest, 52 YALE L.J. 1, 2 (1942). For some elaboration on the in-group/out-group sociological notion, see Cover, supra note 1, at 1297-300 \& n.37.

108. 446 U.S. 55 (1980). 


\section{of discriminatory intent, Congress amended section 2 of the Voting} Rights Act in 1982 to outlaw state or local electoral schemes or processes that result in the electoral exclusion of a minority community. ${ }^{109}$

In Thornburgh v. Gingles, ${ }^{10}$ the Supreme Court established standards for applying this discriminatory effects test. In a nutshell, the test is whether under the challenged electoral scheme "a bloc voting majority [is] usually ... able to defeat candidates supported by a pohtically cohesive, geographically insular minority group."111 According to public choice theory, as discussed by Ackerman, we should never encounter this situation, given the organizational advantages of a "pohtically cohesive, geographically insular minority group" and the low likelihood of "1najority bloc voting." Yet numerous lower courts have recently found violations of section 2 under this standard. ${ }^{112}$

The evidence does not so much prove Ackerman wrong as suggest

109. Voting Rights Act Amendments of 1982, Pub. L. No. 97-205, 96 Stat. 131 (current version at 42 U.S.C. $\S \S 1973$, 1973b, 1973aa-1a, 1973aa-6a (1988)). Section 2, as amended, provides:

(a) No voting qualification or prerequisite to voting or standard, practice, or procedure shall be imposed or applied by any State or political subdivision in a manner which results in a denial or abridgement of the right of any citizen of the United States to vote on account of race or color .....

(b) A violation of subsection (a) of this section is established if, based on the totality of circumstances, it is shown that the political processes leading to nomination or election in the State or political subdivision are not equally open to participation by members of a class of citizens protected by subsection (a) of this section in that its members have less opportunity than other members of the electorate to participate in the political process and to elect representatives of their choice. The extent to which members of a protected class have becn elected to office in the State or political subdivision is one circumstance which may be considered: Provided, That nothing in this section establishes a right to have members of a protected class elected in numbers equal to their proportion in the population.

42 U.S.C. $\$ 1973$ (1988).

110. 478 U.S. 30 (1986).

111. Id. at $48-49$.

112. See, e.g., White v. Daniel, 909 F.2d 99 (4th Cir. 1990) (district court finding of section 2 violation reversed on other grounds); Whitfield v. Democratic Party, 890 F.2d 1423 (8th Cir. 1989) (primary election runoff requirement struck down as violative of section 2), cert. denied, $111 \mathrm{~S}$. Ct. 1089 (1991); Collins v. City of Norfolk, 883 F.2d 1232 (4th Cir. 1989) (at-large city council election system violates section 2), cert. denied, $111 \mathrm{~S}$. Ct. 340 (1990); United States v. Dallas County Comm'n, 850 F.2d 1430 (11th Cir. 1988) (finding insufficient district court's remedial plans to address section 2 violation involving at-large electoral systems for county commissioners and school board members), cert. denied, 490 U.S. 1030 (1989); Ewing v. Monroe County, 740 F. Supp. 417 (N.D. Miss. 1990) (county redistricting plans found to violate section 2); Williams v. City of Dallas, 734 F. Supp. 1317 (N.D. Tex. 1990) (city council electoral systen consisting of eight single-member districts and three at-large seats violates section 2 ).

White bloc-voting majorities join myriad other restrictive voter registration procedures that disadvantage blacks in the political process. Limitations on the time and place of registration, restrictions on appointment of deputy registrars, and dual registration requirements (such as the requirement that one register once with the municipal registrar to vote in municipal elections and again with the county registrar to vote in county, state, and federal elections) are among the more common restrictive procedures in use today, particularly in the South. Not unlike the poll tax and literacy tests, which the Voting Rights Act of 1965 swept away, such facially neutral procedures have a disproportionately negative impact on blacks. See generally F. PARKER, BLACK Votes 
that his time has not yet come. Ackerman explicitly addresses himself to the future when full minority political participation is commonplace and our "grim history" has been overcome."13 If Ackerman errs, it is in underestimating the tenacious liold of that history. For, once its questionable axiomatic quality is removed, Carolene Products contains a powerful normative message about the judicial protection of "out-groups," a label that still applies to blacks in today's society.

In sum, despite the undeniable and important gains of the last twenty-five years, blacks continue to suffer from substantial disadvantages in the political process. Althougli they no longer suffer froin the stark political impotence of the early twentietli century, Carolene Products remains relevant to their situation today.

\section{The Politics of Affirmative Action: An Empirical Examination of Justice Scalia's Contentions}

In Justice Scaha's first judicial opinion on affirmative action, his dissent in Johnson v. Transportation Agency, ${ }^{114}$ he contended that the plaintiff, Paul Johnson, was denied his riglits under title VII by an affirmative action progranı that favored women. In Justice Scalia's concluding paragraph, he argued that the Court's reading of title VII violated the Court's historic role as a guardian of tlie politically powerless. "It is unlikely," he wrote, "that today's result will be displeasing to politically elected officials, to whon it provides the neans of quickly accommodating the demands of orgarized groups to achieve concrete, numerical iniprovement in the economic status of particular constituencies."115 $\mathrm{He}$ added that "the only losers in the process are the Jolinsons of the country."116 Most telling for our purposes was his final sentence: "The irony is that these individuals - predominantly unknown, unaffluent, unorganizedsuffer this injustice at the hands of a Court fond of thinking itself the chainpion of the pohtically impotent."117

Justice Scalia's coniplamt in Johnson was that the Court, in upholding the affirmative action plan in question, had transformed title VII frons an instruinent of nondiscrimination into an engine of reverse discrimination. The politics of affirmative action might offer support for this proposition in two respects. First, as Justice Rehnquist argued forcefully in his dissent in United Steelworkers $v$. Weber, ${ }^{118}$ affirmative action

Count: Polttical EMPowerment IN MississipPI AFTER 1965 (1990) (describing Mississippi's effort to nullify the black vote after the passage of the Voting Rights Act of 1965).

113. Ackerman, supra note 1 , at 717 .

114. 480 U.S. 616, 657 (1987) (Scalia, J., dissenting).

115. Id. at 667 .

116. Id.

117. Id.

118. 443 U.S. 193, 219-55 (1979) (Rehnquist, J., dissenting). 
may be inconsistent with the original legislative compromise which gave rise to title VII. Second, as Justice Scalia contended in Johnson, affirmative action programs-especially those imvolving government fundsmay be popular with politicians because the beneficiaries are highly organized and the opposition is sparse. ${ }^{119}$ Thus, Justice Scalia pictures affirmative action as a politically one-sided affair, in which the beneficiaries hold all the cards, and the "Paul Johnsons of the world" are defenseless.

The following subsections analyze three eras in civil rights legislation: the 1964 Civil Rights Act, the subsequent birth of affirmative action during the Nixon administration, and finally, the evolution of affirmative action from Ford to Bush. Our analysis finds support for Justice Rehnquist's position that the original meaning of the 1964 Act did not contemplate affirmative action. We are, however, much less inclined to agree with Justice Scalia's public choice arguments. Of course, the definitive study of the pohtics of affirmative action has yet to appear, and our findings are necessarily tentative. Nonetheless, our imquiry raises serious questions about the validity of the assumptions underlying Justice Scalia's attempt to "flip" Carolene Products.

\section{a. The 1964 Civil Rights Act}

The issue of affirmative action arose early in discussions on federal employment discrimination law. In the House hearings, James Farmer, the head of the Congress of Racial Equality, supported "aggressive action to secure the einployment of minorities, ... not in terms of a quota," but by preferring black applicants if they were equally quahfied. ${ }^{120}$ "Isn't that discriminating agamst a white who inay have been innocent of any discrimination agamst anyone else in that time?," asked Representative Peter Rodino, a strong supporter of the bill. ${ }^{121}$ There was equally sharp questioning from William Foley, the general counsel of the subcommittee. ${ }^{122}$

Passage through the House involved coinplex negotiations between the administration, key civil rights supporters, and the Republican leadership in Congress. The crucial procedural move was dislodging the bill from the Rules Cominittee. Although there were other important events, including an amendment adding sex discrimination to the hist of prohibi-

119. See supra notes 5-7 and accompanying text; see also City of Richmond v. J.A. Croson Co., 488 U.S. 469, 524 (1989) (Scalia, J., concurring) (characterizing a local affirmative action program as "a set-aside clearly and directly beneficial to the dominant political group, which happens also to be the dominant racial group").

120. H. GrahaM, ThE CIVil Rights ERA 108 (1990) (quoting James Farmer).

121. Id. at 109 (qnoting Rep. Peter Rodino).

122. Id. 
tions, affirmative action was not discussed. ${ }^{123}$

Even before the bill had passed the House, however, the affirmative action issue was raised im the Senate. Senator Hill of Alabama, a New Deal labor supporter, warned that the civil rights bill would undermine the seniority system by requiring racial preferences. The AFL-CIO responded that the bill did not require racial balance or sanction discrimination against white workers. ${ }^{124}$

The key problem faced by the bill's supporters in the Senate was the certainty of a filibuster. To shut off debate, they needed the support of Everett Dirksen, the Senate minority leader, whose oratory had earned him the nicknaine the "Wizard of Ooze."125 The bill underwent several changes to obtain his support. ${ }^{126}$ For our purposes, the most important change was to strengthen the anti-quota language in Section 703(j). ${ }^{127}$

Affirmative action figured heavily in the Senate debates. Opponents charged that the bill would require racial balance and preferential hiring, while supporters repeatedly rebutted these arguments. Senators Clark and Case, the floor captains, submitted an interpretive inemorandun analyzinig the bill. Even if an einployer had discriminated in the past, they said, "[h]e would not be obliged -or mdeed permitted-to . . prefer Negroes for future vacancies. . . "128 Similarly, Senator Huinphrey said that far from requiring quotas, the bill provides "that race, religion and national origin are not to be used as the basis for hiring and firing." 129

Although the historical evidence is complex and not free of ambiguity, our reading of the record is that the supporters of the bill were opposed to preferential hiring for the purpose of obtaning racial balance. ${ }^{130}$ For present purposes, however, it is less important how the

123. For a summary of the bill's journey through the legislative process in the House, see W. Eskridge \& P. Frickey, Cases and Materials on Legislation: Statutes and the Creation of Public Policy 7-17 (1988).

124. H. GrahaM, supra note 120 , at 139-40.

125. W. ESKRIDGE \& P. FRICKEY, supra note 123, at 22.

126. H. GrahaM, supra note 120 , at $146-47$.

127. See id. at 147, 336-37.

128. 110 CoNG. REC. 7213 (1964).

129. Id. at 6549 .

130. Wilham Eskridge, who is a strong supporter of the Weber holding on other grounds, has aptly summarized the major reasons for this conclusion:

I find two things critical. The Civil Rights Act barely beat back the Southern Democratic filibuster in the Senate (by a vote of 71 to 29 , four votes more than the required two-thirds majority), and only with the support of Senator Dirksen and about a dozen other Republican conservatives. It is inconceivable to me that these Senators, as well as some of the Democrats voting to invoke cloture, would have favored a bill that permitted, and even encouraged, voluntary affirmative action plans. With regard to the legislative purpose, the theme that dominated the debates was equality of opportunity and the creation of a colorblind society. The only purpose for which there was substantial congressional consensus was the creation of a color-blind society. 
affirmative action issue was resolved in the Senate than that it was vigorously debated. The "Paul Johnsons of the world" had powerful advocates among the bill's supporters in Congress, who were eager to deinonstrate that the bill would not unfairly disadvantage white workers. The concerns of white workers about preferential hirmg were also well represented by the unions, who were key ineinbers of the coalition that passed the bill. ${ }^{131}$ Thus, although soine may contend that the "Paul Johnsons of the world" lost this round, it is beyond doubt that their interests were well represented.

\section{b. The Birth of Affirmative Action}

Although the Keunedy administration in $1961^{132}$ and the Fifth Circuit during the $1960 \mathrm{~s}^{133}$ provided early mandates for affirmative action programs, the federal government's current level of involveinent with affirmative action began with the "Philadelphia Plan" in the late 1960s. ${ }^{134}$ The plan was a response to blatant segregation in several Philadelphia constrnction unions. In order to foster integration, the plan made the racial coinposition of the work force a factor in awarding federal contracts. As initially formulated, the plan required the low bidder to negotiate hiring goals with the federal agency awarding the contract. ${ }^{135}$ This version of the plan was highly controversial, and it was rescinded in the final days of the Johnson administration-partly because the Comptroller General ruled that such pre-award negotiations violated federal contracting law. ${ }^{136}$

Eskridge, Dynamic Statutory Interpretation, 135 U. PA. L. REV. 1479, 1491 n.46 (1987) (citations omitted).

For further historical evidence, see H. GraHAM, supra note 120, at 139-52; United Steelworkers v. Weber, 443 U.S. 193, 230-52 (1979) (Rehnquist, J., dissenting); Meltzer, The TVeber Case: The Judicial Abrogation of the Antidiscrimination Standard in Employment, $47 \mathrm{U}$. CHI. L. REV. 423 (1980). Just to make our position clear, we should note that, notwithstanding the legislative history, we also agree with Professor Eskridge that title VII should be construed to allow affirmative action when there are statistical indications of past discrimination by an employer. See Eskridge, supra, at 1533 n.214 (interpreting Weber to require that affirmative action be "narrowly tailored to redress past discrimination"); see also Farber, Statutory Interpretation and Legislative Supremacy, 78 GEo. L.J. 281, 305-06 (1989) (arguing that remedial affirmative action is permissible under title VII).

131. H. GrahaM, supra note 120 , at $22,48,139-41$.

132. See Exec. Order No. 10,925, 3 C.F.R. $\$ \S 448,450$ (1959-63 Comp.) (requiring certain federal contractors to take "affirmative action" to guarantee equal employment for blacks).

133. See J. BASS, UNLIKELY HEROES 17-18 (1981) (discussing the development of the doctrine of "affirmative duties" in Fifth Circuit school desegregation cases).

134. For an extensive discussion of the plan, and of the congressional reaction to it, see Comment, The Philadelphia Plan: A Study in the Dynamics of Executive Power, 39 U. CHI. L. REv. 723 (1972) (authored by Robert P. Schuwerk).

135. H. GRAHAM, supra note 120 , at 289-90.

136. Id. at $295-96$ (citing Comptroller General's ruling that "[a]n award may not properly be withheld pursuant to the Plan from the lowest responsive and otherwise responsible bidder on the 
Surprisingly, the plan was resurrected by the Nixon administration. A revised version of the plan required that bid mvitations include target ranges (rather than quotas). ${ }^{137}$ Even with this modification, the Comptroller General ruled that the plan was illegal. ${ }^{138}$ Labor Solicitor Laurence Silberman (a future Reagan judicial appointee) and Attorney General John Mitchell prepared briefs defending the legality of the plan. ${ }^{139}$

The plan drew strong opposition in Congress. Everett Dirksen argued that the plan violated title VII, but he died that same year; the AFL-CIO attacked the plan; and Senator Ervm opened a vociferous campaigu against it. ${ }^{140}$ Ultimately, the Senate passed (52-37) an appropriations rider offered by Senator Byrd, which mandated compliance with the rulings of the Comptroller General. ${ }^{141}$ At this point, Richard Nixon became the unlikely hero of affirmative action. He campaigned hard in the House to have the appropriations rider rejected. ${ }^{142}$ The House voted against the rider, with the crucial margin coming from Republicans. ${ }^{143}$ The Philadelphia Plan then became the foundation for an executive order mandating affirmative action nationwide in federal contracting. ${ }^{144}$

Why did the Nixon admimistration throw its weight behind the Philadelphia Plan? There seem to have been at least three reasons. First, within the administration, the champion of the plan was Secretary of Labor George Shultz, who was an economic conservative but a strong behever im civil rights. ${ }^{145}$ Second, Nixon needed to maintain the support of the liberal wing of the party; he may also have had thoughts of regainmg the substantial black support he had received in $1960 .{ }^{146}$ Finally, Nixon shrewdly saw affirmative action as a wedge with which to split organized labor away from the civil rights movement, thereby breaking

basis of an unacceptable affirmative action program, until provision is made for informing prospective bidders of definite minimum requirements to be met").

137. Id. at 327.

138. Id. at 331 .

139. Id. at 330,333 . Ultimately, the plan was upheld in Contractors Association v. Sccrctary of Labor, 442 F.2d 159 (3d Cir.), cert. denied, 404 U.S. 854 (1971).

140. H. GRAHAM, supra uote 120, at 335-37. The Comptroller General continued to insist on the illegality of the plan. Id. at 339.

141. Id. at $339-40$.

142. President Nixon threatened to veto the appropriations bill if it contained the rider, whereas, at a press conference, Secretary of Labor George Shultz called the House vote on the rider "the most important civil rights vote in a long, long time." Comment, supra note 134, at 749 \& n.141.

143. H. GRAHAM, supra note 120 , at 340 .

144. See id. at 341-43; see also Comment, supra note 134, at 753-57 (discussing the numerous legislative proposals and debates leading to congressional ratification of the executive order affirmative action requirements).

145. H. GRAHAM, supra note 120 , at 322-25.

146. See id. at $302-03,322$. 
the New Deal coalition. ${ }^{147}$

Much the same story was replayed during the passage of the 1972 amendments to title VII. Senator Ervin offered an anti-Philadelphia plan amendment to title VII, but was successfully countered by Senator Javits (a liberal Republican from New York), with strong support from the Secretary of Labor. ${ }^{148}$

The survival of the Philadelphia Plan, and with it affirmative action in federal contracting, did not reflect overwlelming political strengtli by organized civil rights groups. Nor did it reflect political powerlessness by the "Paul Johnsons of the world," whose position was defended by the Comptroller General, a large number of Senators (enougli to pass the Byrd amendment), and the labor umions. Rather, affirmative action survived these imitial tests for two reasons. First, some important actors (especially Shultz) favored it for ideological reasons. Second, support of affirmative action was seen as useful for party reasons. Liberal Republicans needed black votes as part of their electoral coalitions, and Nixon needed liberal Republicans as part of his own electoral coalition. Nixon also saw affirmative action as a way of sphtting the Democratic coalition. In otler words, affirmative action survived in the early 1970s as a result of the norinal operation of classic pluralist politics, not because of the supposed advantages that discrete and insular groups hold over their opponents. ${ }^{149}$

\section{c. Affirmative Action From Ford to Bush}

We will offer ouly a brief survey of later developments regarding affirmative action, focusing on four episodes. The first is the 1977 Public Works Employment Act, ${ }^{150}$ which became the subject of the Court's decision in Fullilove v. Klutznick. ${ }^{151}$ The Act contained a minority setaside provision, requiring that ten percent of the funds appropriated go to minority busmesses (with some qualifications not relevant here). ${ }^{152}$ The minority set-aside was a floor amendment offered by Representative Mitcliell. There were no hearings or cominittee reports; ${ }^{153}$ in the Senate, a similar provision was adopted witliout debate. ${ }^{154}$

147. Id. at 325,340 . This "wedge" strategy was extraordinarily successful. See Edsall, The Hidden Role of Race, THE NEW REPUBLIC, July 30, 1990, at 35, 38.

148. H. GRAHAM, supra note 120, at 440-43.

149. For a discussion of Ackerman's theory that minority groups have greater political power due to their discreteness and insularity, see supra text accompanymg notes 60-74.

150. Pub. L. No. 95-28, 91 Stat. 116 (codified in significant part at 42 U.S.C. $\S \S 6705(e)-6707(j)$

(1982)). For a fuller discussion of the statute and its adoption, see Days, Fullilove, 96 YALE L.J. 453, 463-66 (1987).

151. 448 U.S. 448 (1980).

152. Id. at 454.

153. Id. at 458-61.

154. Id. at 456-63. 
This episode is open to several interpretations. Justice Stevens, perhaps uncharitably, described the set-aside's origins as follows: "The legislative history of the Act discloses that there is a group of legislators in Congress identified as the 'Black Caucus' and that inembers of that group argued that if the Federal Government was going to provide $\$ 4$ billion of new public contract business, their constituents were entitled to "a piece of the action." "155 From this perspective, the program had the indicia of special-interest legislation. On the other hand, the provision can also be seen as a last-minute effort to ensure the fair distribution of the benefits of a Keynesian spending measure, in a situation where time was of the essence. ${ }^{156}$

A similar, but less well-known, provision was enacted in 1983. The Surface Transportation Assistance Act ${ }^{157}$ raised the federal gasoline tax by five cents. In authorizmg highway construction appropriations, section 105(f) contained a ten-percent set-aside for "small business concerns owned and controlled by socially and economically disadvantaged individuals."158 Like the Fullilove statute, this provision originated as a floor amendment by Representative Mitchell. Again, there were no hearings or committee reports. ${ }^{159}$

Although these two episodes inay not represent legislative deliberation at its best, nonetlieless they provide hittle support for the Scalia thesis that minority groups are more powerful than the victims of affirmative action. Floor amendinents often are a back door approach to the legislative process. Groups that have systematic advantages in the legislative process need not rely exclusively on floor amendinents because they can obtam favorable committee consideration. ${ }^{160}$ The fact that a group uses these techniques does not prove its lack of political power, but neither does it indicate the group's political dominance.

A third episode involved another back door, the appropriations rider. In 1977, under a mandate from the D.C. Circuit, the Federal Cominumications Commission developed two policies giving licensing

155. Id. at 541-42 (Stevens, J., dissenting).

156. The argument is that this public works bill was adopted as a measure to stimulate the flagging economy, and the government had to spend the funds proinptly, when they could help the economy rebound, and not after a recovery had already occurred, when the spending might fuel inflation. Farber \& Frickey, The Jurisprudence of Public Choice, 65 TEX. L. REV. 873, 918 n.255 (1987).

157. Pub. L. No. 97-424, 96 Stat. 2097 (1983).

158. Id. § $105(\mathrm{f}), 96$ Stat. 2100.

159. The history of this provision is recounted in Days, supra note 150 , at $472-73 \mathrm{n} .98$. Days also mentions a similar set-aside in a foreign aid statute. Id. at $474 \mathrm{n} .99$ (citing the Foreign Assistance Act of 1961, Pub. L. No. 98-151, 97 Stat. 964, 970-71 (1983)).

160. Congressional committees are often ideologically skewed toward the interests of powerfu] clientele groups. See R. Davidson \& W. Oleszek, Congress and ITS MEMBERs 220-21 (2d ed. 1985). 
preferences for minority-owned business. ${ }^{161}$ In 1985 , as the result of another D.C. Circuit decision involving hicensing preferences for woinen, the FCC began a reconsideration of the minority preferences. ${ }^{162}$ The House and Senate subcommittees with jurisdiction over telecominunications held extensive hearings and considered legislation to codify the FCC's existing policies. ${ }^{163}$ Ultimately, however, rather than passing substantive legislation, Congress enacted several appropriations riders banning the FCC from using any appropriated money to continue its reconsideration. ${ }^{164}$ Since the relevant committees appeared to support the measure, the use of an appropriations rider was presumably intended to avoid a possible presidential veto, given the Reagan administration's strong opposition to affirmative action. ${ }^{165}$

This brings us to the final episode, which also involved the Reagan administration. As mentioned earlier, the Philadelphia Plan resulted in a wide-reaching executive order mandating affirmative action by governinent contractors. ${ }^{166}$ As part of its vigorous campaign against affirmative action, the Reagan administration proposed to eliminate inost federally mandated affirmative action plans. ${ }^{167}$ Not surprisingly, the proposal was strongly opposed by civil rights groups; nore surprisingly, the business community was also strongly opposed. ${ }^{168}$ Ultimately, in part because of a Suprene Court decision that authorized soine forms of affirmative action, the executive order remained intact. ${ }^{169}$ This outcome is especially striking since it cannot be blained on agenda control by congressional leaders, committee power to block new legislation, or other structural factors-because, of course, the President can change executive orders unilaterally, without any congressional action.

This final episode points up the single biggest problenı with Justice Scalia's theory. The supposed political powerlessness of opponents of affirmative action ignores the role of the very President who (not coincidentally) apponited Justice Scalia himself. The "Paul Johnsons of the

161. These policies were at issue in Metro Broadcasting v. FCC, $110 \mathrm{~S}$. Ct. 2997, 3004-05 (1990).

162. See id. at 3006. The D.C. Circuit opinion on preferences for wonten was Steele v. FCC, 770 F.2d 1192 (D.C. Cir. 1985).

163. Metro Broadcasting, $110 \mathrm{~S}$. Ct. at 3015-16.

164. Id. at 3006, 3016. Specifically, the 1988 provision said that "none of the funds appropriated by this Act shall be used to repeal, to retroactively apply changes in, or to continue a reexamination of" the Commission's existing minority preferences. Pub. L. No. 100-202, 101 Stat. 1329-31 (1987).

165. For a full description of the Reagan administration's activities regarding affirmative action, see Devins, Affirmative Action After Reagan, 68 TEX. L. REv. 353 (1989).

166. See supra text acconipanying note 144 .

167. See Devins, supra note 165 , at 355 n. 13 .

168. Conment, Rethinking Weber: The Business Response to Affirmative Action, 102 HARv. L. REv. 658, 662 (1989).

169. See Devins, supra note 165 , at 355 n.13. 
world" had no small ally in the person of Ronald Reagan, who was a persistent-if not always successful—opponent of affirmative action. ${ }^{170}$ The Bush administration has also been staunchly opposed to the use of quotas, which was a major reason for its opposition to the 1990 civil rights act. ${ }^{171}$

At one extreme, affirmative action might be portrayed as the product of a civil rights juggernaut. At the other, its continued existence inay derive solely froin the power of liberal Democrats in key coininittees to block corrective legislation. ${ }^{172}$ The reality seems to be somewhere in between. Affirmative action has commanded inajority support at various times in both houses of Congress, but it has also faced soine serious opposition and has often succeeded only through various strategic maneuvers. The pohtics have been far more complex than a simple battle between diffuse groups and discrete minorities, as portrayed by Ackerman and Scaha. To the extent this history suggests any model of racial politics, it is closer to conventional pluralism than to the Ackerman/Scatia thesis. And as we have suggested, the pluralist bargaining may have been somewhat tilted agamst blacks because of their legislative underrepresentation. ${ }^{173}$

\section{III}

\section{Carolene Products and the Future of AfFirmative ACTION IN THE SUPREME COURT}

It may be time to pause and take stock. The political theory espoused in Carolene Products has long held a key position in civil rights debate. In the heat of the fray, however, the practical inportance of Carolene Products' political theory has become distorted. Thus, in Part I, we reexamined the bedrock civil rights cases such as Brown v. Board of Education and found that the essential lesson of Carolene Products was more normative than positive. As a result, controversies over the continumg validity of the Carolene theory do not endanger the foundation of civil rights jurisprudence.

Nonetheless, the contention that Carolene Products was simply bad pohtical science cannot be ignored. Accordingly, in Part II, we evaluated this contention and challenged the critics on both a theoretical and

170. Although he was more vocal, Reagan was not the first President to oppose affirmative action. Gerald Ford had also done so, though to little effect. See N. GLAZER, supra note 11, at 179. Notably, even President Reagan signed some bills that contained affirmative action provisions. Jones, The Genesis and Present Status of Affirmative Action in Employment: Economic, Legal, and Political Realities, 70 Iowa L. REv. 901,940 (1985).

171. See Letter from Attorney General Richard Thornburgh to Senator Edward Kennedy 1, 4 (Apr. 3, 1990).

172. See Eskridge, supro note 130 , at $\mathbf{1 5 2 5 .}$

173. See supra text accompanying notes 75-113. 
an empirical level. In particular, we rejected Justice Scalia's effort to use modern political theory to use Carolene Products as a vehicle for heightened judicial concern about legislative decisions that harm diffuse majorities (for example, whites or males).

Because the pressures to abandon or to "flip" Carolene Products are most acute in the affirmative action cases, these cases will be one acid test of Carolene's future role. ${ }^{174}$ In this Part, we focus on the two primary arguments for abandoning affirmative action programs under title VII, one based on "flipping" Carolene's political theory, and the other based on more traditional methods of imterpreting the statute.

Section III(A) examines the first argument and rejects it for reasons flowing directly from the discussion in Part II. Section III(B) then addresses the statutory interpretation argument. Although the legislative history of title VII indicates that it was probably not intended to imclude affirmative action, the Court's holdings im favor of affirmative action and the subsequent congressional silence strongly counsel against any reversal of position. Carolene is relevant to assessing the significance of this congressional silence.

\section{A. Affirmative Action and Carolene Products Today: An Uneasy Equilibrium}

At the time of this writing, the Court may have reached an (uneasy) equilibrium on affirmative action. As a constitutional matter, Richmond v. J.A. Croson Co. ${ }^{175}$ established that strict scrutiny applies to local affirmative action measures, ${ }^{176}$ while Metro Broadcasting v. $F C C^{177}$ held that at least the federal affirmative action measure at issue there should be judged under an intermediate scrutiny standard like that applied in gender discrimination cases. ${ }^{178}$ When private, voluntary affirmative

174. If we were operating with a blank slate, the lessons of Parts I and II would provide direct guidance on resolving these disputes: Racial discrimination is not the same, normatively or empirically, as affirmative action, and the standard of judicial review should be differentiated accordingly. This does not mean, of course, that all affirmative action programs would be upheld, but only that they would face less intensive scrutiny than laws discriminating against racial minorities. The slate is far from blank, however, and the decided cases are inconsistent with our analysis.

175. 488 U.S. 469 (1989) (plurality opinion).

176. Justice O'Connor's plurality opmion on this issue, joined by Chief Jnstice Rehnquist, Justice White, and Justice Kennedy, concluded that strict scrutiny was the applicable standard. Id. at 493-98. Justice Scalia, concurring in the judgment, agreed with that standard of review but concluded that the plurality's approach to applying it was insufficiently rigid. See id. at 520 (Scalia, J., concurring in the judgment).

177. 110 S. Ct. 2997 (1990).

178. Justice Brennan's majority opinion in Metro Broadcasting stated: "We hold that benign race-conscions measures mandated by Congress-even if those measures are not 'remedial' in the sense of being designed to compensate victims of past governmental or societal discrimination-are constitutionally permissible to the extent that they serve important governmental objectives within 
action plans are involved, United Steelworkers v. Weber ${ }^{179}$ is the principal precedent: Weber upheld such a plan against a challenge under title VII. ${ }^{180}$ Johnson $v$. Transportation Agency, ${ }^{181}$ the case in which Justice Scaha vigorously dissented, recently reaffirmed Weber.

There is substantial reason to doubt that this pattern will hold. Justice Brennan's retirement may unravel it, since he cast the critical fifth vote in both Metro Broadcasting and Johnson. ${ }^{182}$ In any event, both the apparent plasticity of the precedents and the controversial nature of affirmative action leave little doubt that the Court will be asked to resolve more such disputes. Future decisions may turn on what role is eventually assigned to Carolene Products.

One possibility would be to apply it in its mitial sense that only discrete and insular minorities should qualify for enhanced judicial solicitude. Such a development would result im enhanced judicial sohcitude for minorities even if they sometimes seem like political "winners" under affirmative action schemes. The "losers" under an affirmative action plan (whites, males) would not qualify for protection under this approach, smce they cannot attribute their loss to "prejudice" against a discrete and insular "minority."

But this scenario is highly unlikely. The original theory of Carolene Products has played little role in tlie constitutional cases. ${ }^{183}$ Although our story of the politics of affirmative action provides some einpirical support for the rejected argument, it is unlikely to change the ininds of tlie Justices in equal protection cases.

The positive pohtical tlieory of Carolene Products has played an even sinaller role in the title VII affirmative action cases. Positive political theory is not very helpful in resolving the essential tension in these cases between the text and original understanding of title VII (which seem to require color-blindness in employment decisions) and the two cross-cuttimg normative factors: supporting Congress' goal of benefiting racial minorities, and accommodating post-enactment developments

the power of Congress and are substantially related to achievement of those objectives." Id. at 300809 (footnote omitted). This standard parallels the approach taken in gender discrimination cases. See, e.g., Craig v. Boren, 429 U.S. 190, 197 (1976) ("[C]lassifications by gender must serve important governmental objectives and must be substantially related to achievement of those objectives.").

179. 443 U.S. 193 (1979).

180. Id. at 200-08. The provisions raised in the challenge were 42 U.S.C. $\S 2000 \mathrm{e}-2(\mathrm{a}),-2$ (d) (1988).

181. 480 U.S. 616 (1987).

182. Four Justices (Rehnquist, O'Connor, Scalia, and Kennedy) dissented in Metro Broadcasting; three Justices (Rehnquist, White, and Scalia) dissented in Johnson, and Justice O'Connor concurred only in the judgment. Since Johnson, Justice Powell, who was in the majority, has left the Court and has been replaced by Justice Kennedy. Thus, even if Justice Brennan were still on the Court, there might well not be five votes for the Johnson majority approach.

183. See supra notes $21-35$ and accompanying text. 
(such as the importance of statistics in employment discrimination law). About all the positive theory of Carolene has to offer is to bolster the normative ideal of protecting disadvantaged minorities by suggesting that the winners, not the losers, under affirmative action are systematically disadvantaged in the political process.

The majority opinion in Weber is based almost solely in normative considerations. It concluded that Congress' essential purpose im adopting title VII was to amehorate " the plight of the Negro in our economy." "184 The Court also stressed that

[i]t would be ironic indeed if a law triggered by a Nation's concern over centuries of racial injustice and intended to improve the lot of those who had 'been excluded froin the American dream for so long' constituted the first legislative prohibition of all voluntary, private, race-conscious efforts to abohish traditional patterns of racial segregation and hierarchy. ${ }^{185}$

In Weber, then, tlie broad goal inherent in title VII's purpose and the incongruities of the contrary result trumped the plam meaning of the statutory text and original legislative expectations. This approach to interpretation has a longstanding pedigree, ${ }^{186}$ but it is becoming imcreasingly controversial. ${ }^{187}$ In fact, the current Court seems more attracted by the ideal of color-blindness than by tlie concerns over status of minority groups so central to Weber.

At present, any incoherence in the positive political tlreory of Carolene Products is likely to be used to undermine, ratlier than bolster, what remains of permissible affirmative action in both the constitutional and statutory arenas. This was, of course, Justice Scalia's argument in his dissent in Johnson, where he asserted that the winners under affirmative action have systematic political advantages and the losers liave corresponding systematic disadvantages. ${ }^{188}$ Similarly, Justice O’Connor's dissent in Metro Broadcasting stressed that one problem with lowering the constitutional scrutimy of affirmative action measures is that it

184. 443 U.S. at 202 (quoting relnarks of Sen. Humphrey).

185. Id. at 204.

186. As Weber partially indicates, these approaches to statutory ineaning are derived froin Church of the Holy Trinity v. United States, 143 U.S. 457, 459 (1892). Quoting froin Holy Trinity, the Court in Weber stated that it is a " 'familiar rule, that a thing may be within the letter of a statute and yet not within the statute, because not within its spirit, nor within the intention of its inakers." " 443 U.S. at 201 (quoting Holy Trinity, 143 U.S. at 459). Holy Trinity also stressed that judges should avoid inuposing an incongruous or absurd interpretation upon a statute. See 143 U.S. at 459.

187. See Public Citizen v. United States, 491 U.S. 440, $469-74$ (1989) (Kennedy, J., concurring in the judgment), which criticized the Court's use of the two approaches rooted in Holy Trinity. Kennedy disparaged the "absurd result" canon because he beheved the Court applied it too freely; he refused to embrace the purpose approach because "it does not foster a denocratic exegesis for this Court to rununage throngh unauthoritative materials to consult the spirit of the legislation in order to discover an alternative interpretation of the statute with which the Court is more coinfortable." Id. at 473 .

188. See supra text accompanying notes 6-10. 
becomes "impossible" to identify "naked preferences for members of particular races," 189 a term we take to mean unjustifiable governmental largesse resulting from the raw political power of the recipient. ${ }^{190}$

Our Parts I and II help rebut this challenge. Our discussion strongly undercuts any attempt to transform the traditional arguinent for slieldimg affirmative action from strict scrutiny into a sword for those clallenging affirmative action. The actual politics of affirmative action lend little support to any argument that whites or males are systematically disadvantaged in the political process and thus are deserving of heiglitened judicial solicitude. Moreover, the continuation of documented barriers to minority political power indicate that civil rights statutes and affirmative action measures are frequently attempts by the majority to undo past wrongs and to promote a more open society. ${ }^{191}$

The traditional judicial tendency to construe civil riglits statutes broadly to protect Carolene groups ${ }^{192}$ is also supported, not undercut, by our understanding of the current pohtical horizon. If affirmative action measures do not deserve a similar judicial embrace, it must be because of the Court's own view that affirmative action is presumptively unjust, rather than any identifiable malfunction im the political process.

At present, it seems unlikely that the Court's general approach to imterpretimg title VII will be based on an informal understanding of the dynamics of civil rights legislation. Sucli an understanding may, however, play a stronger role in the Court's assessment of whether or not to overrule current precedent upliolding affirmative action. It is to these considerations that we now turn.

\section{B. Stare Decisis and the Future of Affirmative Action}

One battle in the near future will likely concern the continuing vitality of Weber and Johnson. Although we have focused on Justice Scalia's flipping of Carolene Products in his Johnson dissent, he also objected to Weber on the ground that the Court was assuining an inappropriate role im statutory interpretation. In his view, the plain language of title VII flatly contradicts Weber, and consequently affirmative action violates the statute.

189. $110 \mathrm{~S}$. Ct. at 3036 (O'Connor, J., dissenting).

190. See Sunstein, Naked Preferences and the Constitution, 84 Colum. L. REv. 1689, 1690 (1984) ("The constitutional requirement that something other than a naked preference be shown to justify differential treatment provides a means, admittedly imperfect, of ensuring that government action results from a legitimate effort to promote the public good rather than from a factional takeover.").

191. For a general discussion of the future-oriented utility of affirmative action, see Sullivan, The Supreme Court, 1985 Term-Comment: Sins of Discrimination: Last Term's Affirmative Action Cases, 100 Harv. L. Rev. 78 (1986).

192. See Eskridge, supra note 56, at 1032-34, 1047-48; Sunstein, supra note 56, at 483-85. 
As we saw above, the historical record also provides support for this interpretation ${ }^{193}$-enough support, we suspect, to be persuasive on that score to an increasingly conservative Supreme Court. Moreover, since Johnson (when Scalia's dissent commanded three votes), two members of the majority have left the Court. Thus a majority of the Court may well be prepared to conclude that Weber was wrong.

At this point, then, the inain support for Weber (and now Johnson) may simply be stare decisis. A key, but controversial, component of deference to statutory precedents is legislative acquiescence. ${ }^{194}$ Since Weber, Congress has failed to take any action regarding private affirmative action. One issue that is almost sure to weigh heavily in any reconsideration of Weber and Johnson is the importance, if any, of this congressional silence. As we shall see, Carolene Products has important implications for considering this legislative inaction.

Johnson itself contained a debate about congressional silence. In response to Scalia's dissent, the Johnson majority responded that "Congress has not amended the statute to reject our construction, nor have any such amendments even been proposed, and we therefore may assume that our interpretation was correct."195 Calling on the majority to abandon the "canard" of "vindication by congressional inaction,"196 Justice Scalia launched a vigorous attack on the presumption that congressional silence constitutes approval of the Court's interpretation of a statute. ${ }^{197}$ As it turned out, this Scalia dissent was only the beginning of a longer battle within the Court over stare decisis.

193. See supra text accompanying notes $120-31$.

194. See, e.g., Eskridge, Overruling Statutory Precedents, 76 GEo. L.J. 1361 (1988).

195. 480 U.S. at 629 n.7.

196. Id. at 672 (Scalia, J., dissenting).

197. He argued that the presumption rests "on the patently false premise that the correctness of statutory construction is to be measured by what the current Congress desires, rather than by what the law as enacted meant." Id. at 671. Justice Scalia made somewhat similar arguments in his dissent in United States v. Johnson, 481 U.S. 681, 702-03 (1987) (Scalia, J., dissenting) ("The unlegislated desires of later Congresses . . . could hardly have any bearing upon the proper interpretation.... And even if they could, intuiting those desires from congressional failure to act is an uncertain enterprise....") (emphasis in original).

Several colnmentators have also expressed the view that legislative silence is not dispositive because inaction by a current legislature eannot be taken to reveal the desires of a previous one. See Easterbrook, Stability and Reliability in Judicial Decisions, 73 CORNELL L. REV. 422, 426-29 (1988) ("Today's Congress may leave in place an interpretation of a law simply because today's coalitions are different. The failure of a different body to act hardly shows that the interpretation of what an earlier one did is 'right.'"); Posner, Economics, Politics and the Reading of Statutes and the Constitution, 49 U. CHI. L. REV. 263, 275 (1982) ("The deal is struck when the statute is enacted. If courts paid attention to subsequent expressions of legislative intent not eunbodied im any statute, they would be unraveling the deal."). On the limitations of stare decisis itself as an interpretive device, see Rees, Cathedrals Without Walls: A View From the Outside, 61 TEx. L. Rev. 347, 373-78 (1982) ("In cases where the judge's role is to apply and interpret laws that have been made by others, prior judicial opinions may contain highly persuasive arguments about what the laws mean, but they cannot relieve the judge of his obligation to decide."). 
Stare decisis and its role in civil rights legislation received broad public attention in 1988, ${ }^{198}$ when the Supreine Court ordered reargument in Patterson v. McLean Credit Union ${ }^{199}$ in order to consider whether to overrule Runyon v. McCrary. ${ }^{200}$ The Patterson reargument order reopened the debate begun in Johnson about the relevance of the "sounds of silence" to stare decisis issues. ${ }^{201}$

After rearguinent, the Patterson Court decided against overruling Runyon. ${ }^{202}$ Although the decision against overruling was unanimous, there was sharp disagreement on the issue of legislative silence. Justice Brennan's dissent accused the majority of glossing over an obvious argument for reaffirming Runyon, which was that Congress had in effect ratified the decision. ${ }^{203}$ In turn, Justice Kennedy's majority opinion

198. For example, the decision was the leading story in the next day's New York Times. Court, 5-4, Votes to Restudy Rights in Minority Suits, N.Y. Times, Apr. 26, 1988, at 1, col. 6. The subtitle was Extraordinary Action Could Lead to Retrenchment on Earlier Protections. According to Newsweek, "liberals on and off the court were aghast at their vision of a new conservative majority, created when Justice Antliony Kennedy joined the bench in February, running roughshod over legal precedents." Why Open a Closed Case? Upheaval on the Court, NEwSwEEK, May 9, 1988, at 69. The New Republic commented that:

Witl so many hberal doctrines now woven in "the fabric of our law," liberals like the idea that they should be preserved even if most justices think they are wrong. Conservatives complain that this notion turus the Supreme Court into a one-way legal ratchet: liberal majorities add new doctrines but conservative majorities can't subtract them. How much respect the Court should give its own past rulings is a perennial question that will be paramount in the coming years. Certainly, tlough, it represents an extreme approach for the Court to announce it lias decided to rcopen an old controversy when nobody has even asked it to do so.

"TRB," The Fifth Man, NEw Republic, May 16, 1988, at 4, 42; see also Greenberg, Distressing Signals From the Court, N.Y. Times, May 18, 1988, at 31, col. 2 (criticizing the Court's invitation to "refight the civil rights battles of the last two decades"); Neuborne, The Run on Runyon: Will Stare Decisis Become Bankrupt?, Legal Times, May 9, 1988, at 16 ("overruling Runyon would be a drcadful mistake").

Justices Blackmun and Stevens filed strong dissents to the reargument order. See 491 U.S. at 621 (Blackmun, J., jomed by Brennan, Marsliall, and Stevens, JJ., dissenting) (sharply criticizing the Court's decision "to reconsider an interpretation of a civil rights statute that so clearly reflects our society's earnest commitment to ending racial discrimination, and in whicl Congress so evidently lias acquiesced"); id. at 621-22 (Stevens, J., joined by Brennan, Marshall, and Blackmun, JJ., dissenting) (arguing that the Court's decision "is certain to engender widespread concern," and will "lave a deleterious effect on the faith reposed by racial minorities in the continuing stability of a rule of law").

199. 485 U.S. 617 (1988).

200. 427 U.S. 160 (1976) (holding that section 1981 prohibits discrimination by private parties as well as by state governments). Runyon involved racial discrimination by a private school. The lower courts liad anticipated the Runyon holding. See C. ABERNATHY, CIVIL RIGHTS: CASES AND MATERIALS 265-76 (1980).

201. The musical allusion derives from Tribe, Toward a Syntax of the Unsaid: Construing the Sounds of Congressional and Constitutional Silence, 57 IND. L.J. 515 (1982) (quoting P. Simon, The Sounds of Silence, sound recording on the album WEDNESDAY MORNING, 3 A.M. (Columbia, 1965)). For background on the issue of congressional silence, see W. ESKRIDGE \& P. FRICKEY, supra note 123, at 307-22.

202. Patterson v. McLean Credit Union, 491 U.S. 164, 169-78 (1989).

203. Id. at 200-05 (Brennan, J., dissenting). Justice Brennan conceded that "the absence of 
responded that the Court's failure to rely on congressional inaction was no oversight:

[C]onsiderations of stare decisis have added force in statutory cases because Congress may alter what we have done by amending the statute. ... It does not follow, however, that Congress' failure to overturn a statutory precedent is reason for this Court to adhere to it. It is "impossible to assert with any degree of assurance that congressional failure to act represents" affirmative congressional approval of the Court's statutory interpretation. [Citing Justice Scalia's Johnson dissent.] Congress may legislate, moreover, only through the passage of a bill which is approved by both Houses and signed by the President. See U.S. Const., art. I, $\S 7$, cl. 2 . Congressional inaction cannot amend a duly enacted statute. ${ }^{204}$

This passage coines close to rejecting completely the idea of relying on legislative silence, thereby repudiating the Johnson majority sub silentio. But while each of the two arguments in the passage has some strength, neither leads to the conclusion that congressional inaction lacks interpretive value.

First, Justice Kennedy is clearly correct that silence need not indicate congressional approval. Congress inay fail to act even though a majority of its members disapprove of a judicial decision. Perhaps the most notable reason is the power of committees and party leaders to control the congressional agenda. ${ }^{205}$ A shift in coahitions can also block efforts to overturn a judicial interpretation, even though the statute would not have passed initially if Congress could have foreseen the Court's later interpretation. ${ }^{206}$ These possibilities simply justify the exercise of caution, however, and not the complete rejection of legislative silence as evidence of congressional approval. The weight to be accorded congressional silence depends on the plausibility of the alternative explanations. For example, in an area like civil procedure-to which Congress is usually quite inattentive-silence means little. ${ }^{207}$ In other circumstances, however, congressional silence may be quite revealing.

There would be a strong case for ignoring congressional inaction if it were attributable to a systematic bias in the political process agamst the

legislative correction is by no means in all cases determinative," but argued that when a judicial interpretation was plausible, "we have often taken Congress" subsequent inaction as probative to varying degrees, depending upon the circumstances, of its acquiescence." Id. at 200.

204. Id. at $175 \mathrm{n} .1$.

205. For a formal model developing this point, see S. Marks, A Model of Judicial Influence on Congressional Policynaking: Grove City College v. Bell (1984) 5-8 (May 1989) (doctoral dissertation available on microfiche at the University of Michigan Library).

206. See Eskridge, supra note 130, at 1524-25.

207. Perhaps this observation explains why the Court gave no thought to legislative silence in a recent case involving an arcane point of appellate practice, even though the result was to overturn a fifty-year-old interpretation of the governing statute. See Gulfstream Acrospace Corp. v. Mayacamas Corp., 485 U.S. 271, 279-88 (1988). 
group aggrieved by a judicial decision. In other words, if the Scalia/ Ackerman thesis were valid, congressional silence could be dismissed as merely a product of the political powerlessness of the "Johnsons of the world." As we have seen, however, the history of affirmative action does not support this thesis. Although the story is complex and does not lend itself to easy morals, it is clear that opposition to affirmative action las been strongly if sometimes unsuccessfully voiced. If anything, there is some ground to think that blacks are underrepresented in the process, and therefore that the deck is still somewhat stacked against affirmative action.

Justice Kemiedy's second argument is that giving weight to congressional silence would violate the article I lawmaking procedures. This argument implicitly views any event that affects the interpretation of a statute as if the event were amending the statute. ${ }^{208}$ What Justice Kennedy seemingly fails to realize is that the same logic would coinpletely mvalidate stare decisis in statutory cases. Stare decisis means that a post-enactment event (namely, a Supreme Court opinion) can "change" the legal meaning of a statute, and by Kennedy's reasoning such a postenactment event is im essence an amendinent to the statute. Obviously, the Court has no power to amend statutes, and thus by this logic the Court ought to accord no weight to its own statutory precedents. ${ }^{209}$

Justice Kennedy's two arguinents do show that congressional silence caimot have the same status as an act of lawmaking. But, as William Eskridge has argued, congressional silence is important when the judicial interpretation of a statute authoritatively sets the course for the statute's future application. ${ }^{210}$ Congressional silence can be an indication that a judicial decision has becoine a "building block," part of the social and pohtical structure. Overruling sucle a foundational interpretation would be particularly disruptive.

We believe that Weber has become just such a "building block"

208. The implicit logic is as follows:

Proposition 1. If weight is given to congressional silence, then post-enactment events will change the meaning that would otherwise be given the statute.

Proposition 2. Any post-enactment event that changes the meaning of a statute in essence amends the statute, and therefore must comply with article I.

Proposition 3. Therefore, giving weight to congressional silence violates article $\mathrm{I}$.

209. Indeed, by the same reasoning, an administrative interpretation cannot properly be given deference. If a court gives a statute a different meaning because of the agency's interpretation, then the agency's announcement of its interpretation has changed the meaning of the statute. By Kennedy's reasoning, this would appear to be a plain violation of article I.

210. Eskridge, Interpreting Legislative Inaction, 87 Mich. L. Rev. 67, 110-11, 120-24 (1988); see also Farber, Statutory Interpretation, Legislative Inaction, and Civil Rights, 87 MicH. L. REv. 2, 13, 18-19 (1988) (expressing similar concerns about the dangers of upsetting "building block" decisions on which the legislature and the public have relied). 
decision. ${ }^{211}$ We find telling supporting evidence in the intellectual journey of sociologist Nathan Glazer. ${ }^{212}$ In the early 1970s, Glazer was a prominent critic of affirmative action. ${ }^{213}$ By the end of the 1980s, however, he had becoine convinced that affirmative action is here to stay:

[I]t seems clear that uprooting affirmative action would be very difficult.

The Reagan administration is as determined an opponent as we are ever likely to see. But after about fifteen years of affirmative action, we have created expectations among blacks and practices in business and government that sustain it. Whatever black doubts about affirmative action there may be (and they do exist), moving against it would appear to black leaders, and to other blacks, as an attack on their mterests and their wellbeing. ${ }^{214}$

Stare decisis is a discretionary doctrine, in which one factor is clearly the existence of settled expectations. ${ }^{215}$ Those expectations strongly favor upholding affirmative action.

The same holds true for the lesson of Carolene Products in its positive form. As we have seen, blacks and other minority groups have not yet obtained pohitical parity. Their successes, like affirmative action, have been hard-won battles, not the easy victories of dominant interest groups. Frequently, as in a series of "civil rights restoration acts," minorities have had to battle mightily smiply to remain where they were. Given a choice, the Court ought not throw its weight on the scales against that of a "discrete, insular minority."

In considering stare decisis, we have again approached Carolene Products largely in the conventional way, through the lens of "process theory." 216 Republicanism offers an alternative perspective on protection for discrete, insular groups that suffer pervasive prejudice. ${ }^{217}$ Such "outgroups" nray require special consideration from the courts because of the risk that otherwise they will be excluded from the civic cominunity. On

211. On prudential reasons to avoid overruling foundational precedents, see Richard Posner's comment quoted at supra note 38.

212. Glazer is a Harvard sociologist and cofounder of The Public Interest. More to the point, he is one of the nation's leading experts on the role of ethnic groups in American society.

213. See H. Graham, supra note 120 , at 457-58.

214. Glazer, The Affirmative Action Stalemate, 90 THE PUB. INTEREST 99, 111 (1988).

215. For a recent discussion of the bases for stare decisis, see Comment, Constitutional Stare Decisis, 103 HaRv. L. REV. 1344, 1349-51 (1990).

216. See supra text accompanying notes 17-19.

217. For an overview of the burgeoning hiterature assessing the revival of republicanism, see Symposium: The Republican Civic Tradition, 97 YALE L.J. 1493-723 (1988) (12 articles and comments reaching various conclusions on this revival); Fallon, What Is Republicanism, and Is It Worth Reviving?, 102 HARV. L. REV. 1695 (1989) (acknowledging that "the study of classical republicanism . . . currently occupies some of our most provocative and insightful constitutional scholars," but concluding that "hopes for the ultimate success of the republican revival should be both cautious and tentative"); Redish \& Lippman, Freedom of Expression and the Civic Republican Revival in Constitutional Theory: The Ominous Implications, 79 CAL1F. L. REV. 267 (1991) (republicanism threatens foundations of free speech rights). 
such a reading, Carolene Products is again quite relevant to affirmative action, as inuch for its normative as its empirical coinponent.

The republican argument for affirmative action is based on the importance of civic community. ${ }^{218}$ Because participation in the commumity is for republicans a basic element of human thriving, exile or inarginalization is a grave injury to mdividuals. It also weakens the community itself by undermining its unifymg civic bonds, while eroding the political process by converting a dialogue between fellow citizens into an adversary relationship. For this reason, the law should avoid communicating messages of exclusion toward potential outsiders. This has been an important factor in judicial decisions such as Brown, phrased as a concern about "mvidious discrimination." 219

Whether or not discrimination is the dominant cause of minority disadvantage, minority group members feel strongly and not unreasonably that it is. ${ }^{220}$ As a result, they are deeply alienated from American social institutions. Majority group members may believe that they have halted all invidious discrimination and that reenaining disparate outcoines are the result of other factors. But minority group inembers are unpersuaded, and they will feel victimized and excluded so long as they see whites in nearly exclusive possession of desirable positions. ${ }^{221}$ Words alone are unlikely to persuade thein that they are welcone inembers of the community. Ouly if the community goes out of its way to include minority group members in key mstitutions will they be persuaded that they are welcome.

The promise of Carolene Products is that groups that are excluded froin full membership in the political cominumity will receive an inviting reception froin the judiciary. To overrule affirmative action decisions such as Weber would, as Glazer points out, have quite the contrary effect. ${ }^{222}$ If Congress (or the courts) had outlawed the Philadelphia Plan

218. This argument is developed in fuller detail in Farber, Richınond and Republicanism, 41 FLA. L. REv. 623 (1989).

219. See supra tèxt accoinpanying notes 30-31.

220. Members of racial minorities, blacks in particular, have reason to feel like outsiders in America. Compared to majority group members in the same socioeconomic class, blacks earn less (even when education and experience are factored in), have higher unemployinent rates, experience grcater housing segregation, receive lower quality education, and have a shorter life expectancy. See R. Brooks, supra note 101, at 25-128. They also have good reason, we think, to believe that much of this situation has ultimately been caused by prejudice and discrimination. Froin some perspectives it may be critical to know whether this perception is accurate or whether factors other than discrimination have contributed to these disparate outcomes, because society is responsible only for correcting the results of its own misdeeds. From the republican perspective, however, the causation issue is less important. See Farber, supra note 218, at 635-37.

221. For a fuller discussion of the inarginalized position of racial minorities, see Karst, Citizenship, Race, and Marginality, 30 WM. \& MARY L. REv. 1 (1988).

222. See supra text accompanying note 214 . 
in 1970 or 1972 , as might well have happened, ${ }^{223}$ this would have been perceived as an unfortunate set-back for minority groups but not a disaster. But twenty years later, at least some kinds of affirmative action are so unquestionably part of American society that to reject them would not merely be a set-back but a slap im the face. If Carolene Products has any normative message at all, it is that "out-groups" deserve an open door from the courts, not a brusque exclusion.

\section{CONCLUSION}

Justice Stone could hardly have foreseen the long and illustrious life of his Carolene Products theory. Endorsed by only four Justices, wrapped in dictum, and buried in a footnote, by all appearances the theory was intended to be nothing more than a suggestion. The concerns that are central to its text-stringently enforcing exphicit constitutional guarantees, and applying them to the states; breaking down barriers to ineaningful political participation; protectimg out-groups against abuseare rooted more in normative than positive theory. In an odyssey of a half-century, its normative vision was the impetus for fundamental constitutional change. Its positive component has fared less well, but does not deserve repudiation for the out-groups Justice Stone envisioned (racial, religious, and national-origin minorities).

It seems time to read Carolene for what it was-a prescient proposal for constitutional evolution. Justice Stone was prophetic about the important matters: exphicit constitutional protections have expanded and become applicable to the states, political structures liave been reformed to make the process fairer, and at least the out-groups he mentioned have received heightened judicial solicitude.

Our review of comparative racial disadvantage and the politics of affirmative action strongly suggest that the core point of paragraph three of footnote four-the protection of racial "out-groups"-should remain a serious judicial concern. Efforts to flip the Carolene argument to engender sympathy for the losers under affirmative action are unpersuasive. We agree with Ackerman's suggestion that Carolene should not operate as a limiting primciple barring meaningful equal protection review to other disadvantaged groups. But in the current judicial chimate in particular, reformers ought to be certain that the baby does not go the way of the bath water. As a description of the political process, Carolene Products unfortunately remains relevant to contemporary politics. As a vision of the just society-one where the inembers of no group are excluded from full civic membership-Carolene Products will always be with us.

223. See supra text accompanying notes $136-49$. 
